Florida International University FIU Digital Commons

FIU Electronic Theses and Dissertations

University Graduate School

$3-28-2013$

\title{
Defining Íśvara: A New Perspective in the Hermeneutics of Classical Yoga
}

Daniella Vaclavik

Florida International University, daniellavaclavik@mac.com

DOI: $10.25148 /$ etd.FI13042313

Follow this and additional works at: https://digitalcommons.fiu.edu/etd

\section{Recommended Citation}

Vaclavik, Daniella, "Defining İ́vara: A New Perspective in the Hermeneutics of Classical Yoga" (2013). FIU Electronic Theses and Dissertations. 839.

https://digitalcommons.fiu.edu/etd/839

This work is brought to you for free and open access by the University Graduate School at FIU Digital Commons. It has been accepted for inclusion in FIU Electronic Theses and Dissertations by an authorized administrator of FIU Digital Commons. For more information, please contact dcc@fiu.edu. 


\title{
FLORIDA INTERNATIONAL UNIVERSITY
}

Miami, Florida

\section{DEFINING ÍSVARA: A NEW PERSPECTIVE IN THE HERMENEUTICS OF CLASSICAL YOGA}

\author{
A thesis submitted in partial fulfillment of the \\ requirements for the degree of \\ MASTER OF ARTS \\ in \\ RELIGIOUS STUDIES \\ by \\ Daniella Vaclavik
}

2013 
To: Dean Kenneth G. Furton

College of Arts and sciences

This thesis, written by Daniella Vaclavik, Defining Íśvara: A New Perspective in the Hermeneutics of Classical Yoga, having been approved in respect to style and intellectual content, is referred to you for judgment.

We have read this thesis and recommend that it be approved.

Andrea Seidel

$\begin{array}{r}\text { Andrea Seidel } \\ \hline \text { Steven Heine } \\ \hline \text { Nathan Katz, Major Professor }\end{array}$

Date of Defense: March 28, 2013

The thesis of Daniella Vaclavik is approved.

\begin{tabular}{r} 
Dean Kenneth G. Furton \\
College of Arts and Sciences \\
\hline Dean Lakshmi N. Reddi \\
University Graduate School
\end{tabular}

Florida International University, 2013 


\section{ACKNOWLEDGMENTS}

I would like to take this opportunity to thank the many people that were involved in this process, either directly or indirectly. Above all, I would like to thank Dr. Nathan Katz, my major professor and advisor, for his constant guidance and support. His confidence in my abilities gave me the encouragement to strive further in this process. I would also like to thank the other members of my committee, Dr. Steven Heine and Dr. Andrea Seidel for their dedication and extensive feedback. To all my professors in the program of Religious Studies who encouraged me as much as they challenged me throughout this journey, and to the department of Religious Studies for giving me this opportunity. To my Sanskrit teacher, Vyaas Houston, for his insightful instruction and inspiration. To my fellow students, for the many discussions regarding my thesis and for helping me navigate this process, specially Mariana Restrepo, as well as Logan Beitmen, Priyanka Ramlakhan, and Nicholas Pearce. Finally, to my family: my husband Peter Vaclavik for his endless support and for always having faith in me, and to Bruno, for always reminding me to approach life one day at a time. 


\section{ABSTRACT OF THE THESIS \\ DEFINING İŚVARA: A NEW PERSPECTIVE IN THE HERMENEUTICS OF \\ CLASSICAL YOGA}

by

Daniella Vaclavik

Florida International University, 2013

Miami, Florida

Professor Nathan Katz, Major Professor

The mere presence of the term iśvara in Patañjali's Yogasütra has come to affect the meaning of both the path and the goal of Classical Yoga as well as the meaning of the term Yoga itself. The frequent translation of the term iśvara as God leads to the system of Classical Yoga to be labeled as theistic, particularly obscuring the interpretation of iśvarapranidhāna, a functional component of the system, as well as perpetuating a syncretic trend that has led to the popular understanding of Yoga as "union with the divine'. From identifying problematic hermeneutical trends and their underlying causes, as well as understanding the term within the constraints of the original text in its original Sanskrit, the term iśvara emerges as the archetype of an ultimate reality functioning as a practical and experiential tool providing the yogi with a direct glimpse of its true nature. 


\section{TABLE OF CONTENTS}

CHAPTER

PAGE

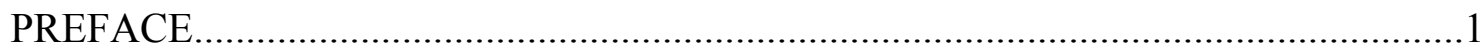

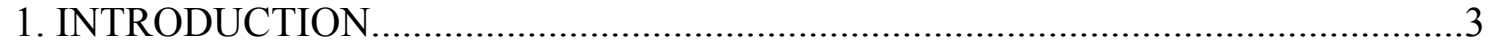

Classical Yoga: The Yogasütra of Patañjali.......................................................

Defining Ísvara: A new Perspective in the Hermeneutics of Classical Yoga.......... 7

Description of Chapters ............................................................................ 14

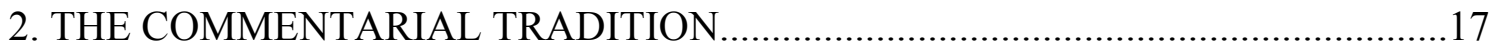

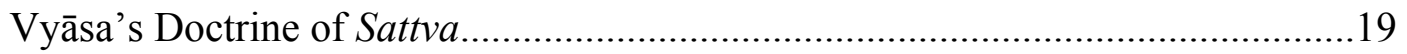

Vijñānabhikṣu’s Syncretic Trend......................................................................22

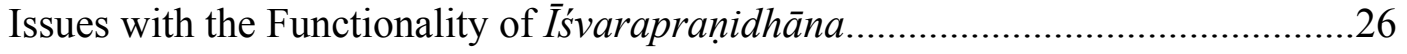

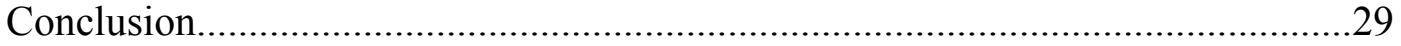

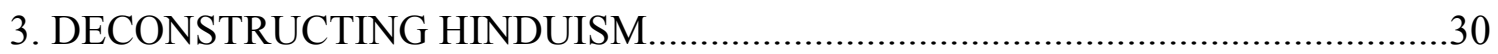

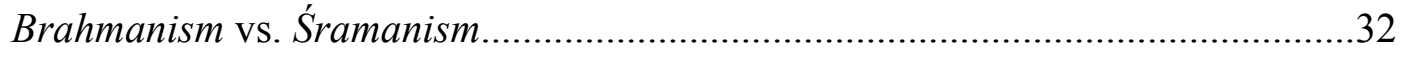

The Caste System and the Monopoly of the Brahmins.......................................37

The Six Darśanas Strengthening the Homogeneity Trend...................................39

Elevating Hinduism as a World Religion................................................... 41

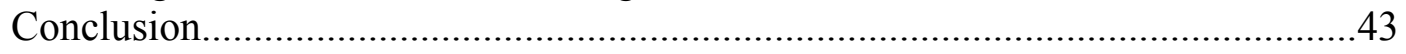

\section{THE ETYMOLOGY OF THE TERM İ́SVARA AND ITS}

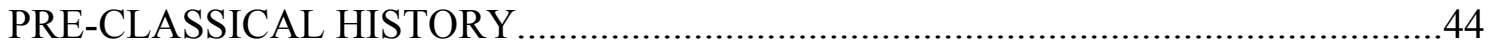

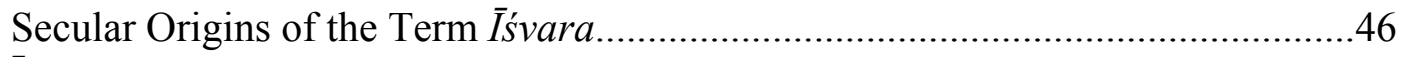

$\bar{I}$ śvara in the Vedas, Brāhmanas, and Upanișads .............................................47

From Worldly Lord to Parameśvara ................................................................49

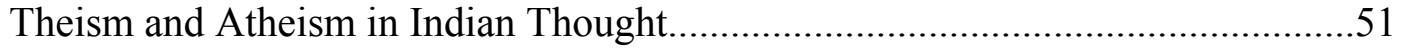

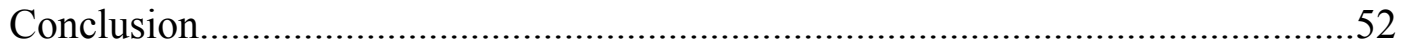

\section{THE PATH OF CLASSICAL YOGA: READING PATAÑJALI}

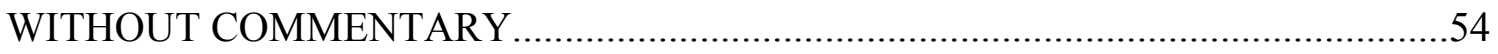

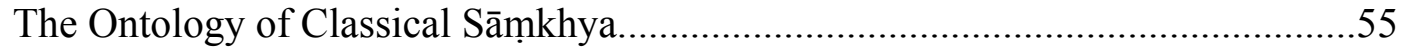

The Path of Patañjala Yoga..............................................................................57

$\bar{I}$ śvarapranidhāna as Concept and Method...........................................................58

The Identity and Use of Íśvara in the Yogasütra...............................................61

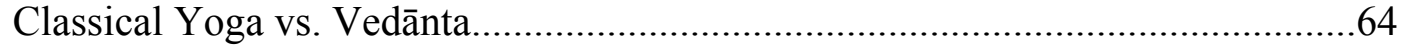

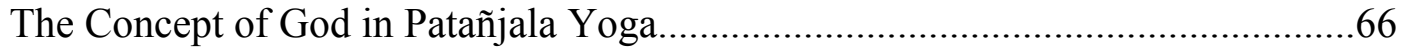

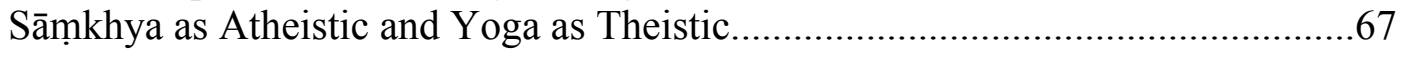

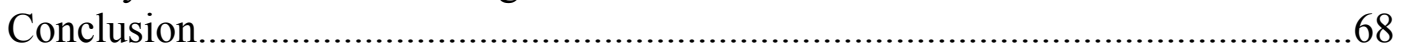

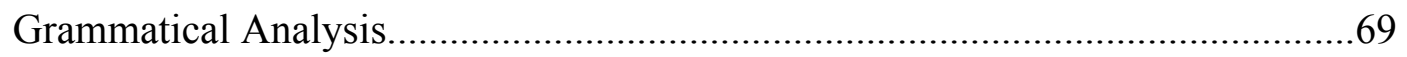

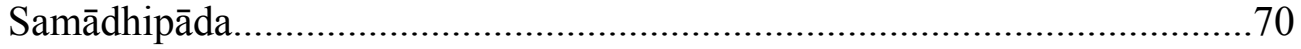

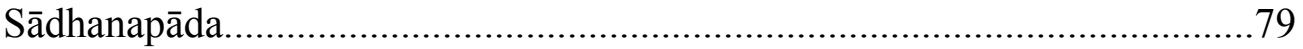


Kaivalyapāda...

6. CONCLUSION.

BIBLIOGRAPHY 


\section{PREFACE}

Since I began my journey into Yoga I have been extremely lucky to have been exposed to highly qualified and exemplary teachers, yet I noticed many of my teachers would use conflicting ideologies as support arguments for their positions, thus attempting to reconcile Classical Yoga with several other ideologies. The most intriguing statement came from my Yoga Guru, Śrī K. Pattabhi Jois, ${ }^{1}$ or 'Guruji', as students affectionately address him. When describing his lineage of Aștanga Yoga he would say: "Aștanga Yoga is Patañjali Yoga”. Since I had been studying the text for some time, I had a particular understanding of what that entailed. To me, it meant he adhered to the philosophy Patañjali followed, mainly, a dualistic model, quite contrary from that of Advaita Vedanta or Bhakti Yoga. Furthermore, when asked by one of his students to define Yoga, Guruji responded: "Yoga is when you see God everywhere". His definition of Yoga, to me, seemed like a complete contradiction of Patañjali's ontology. I was even more intrigued, when I noticed his reconciliation between caste, religion, and practice, for this meant he had different allegiances and ideologies as a Brahmin (priestly caste), a Śaivaite (follower of Śiva), and a Patañjala Yoga guru. For him, it seemed, the contradiction of these three paths was not the least problematic, which seems to be a very common attitude among many practitioners. However, I believe the problem arises when this attitude is translated from personal practice to scholarship, as it may feed the

\footnotetext{
${ }^{1}$ Śrī K. Pattabhi Jois (1915-2009) was an Indian guru from Mysore, India, and the founder of the Kṛṣna Pattabhi Jois Aștanga Yoga Institute (previously the Aștanga Yoga Research Institute).
} 
reductionism of unique and complex systems of thought during the process of reconciliation.

I began graduate school knowing I wanted to further explore the Yogasūtra of Patañjali, yet I was unsure what I wanted to focus on. While studying the text I came across a subject I had purposely ignored since I first became interested in Yoga philosophy: iśvara. All of the teachers I had come across in the past would be reluctant to fully define the nature of iśvara as well as its purpose and functionality within the tradition in a way that satisfied my inquiry. Some simply translated it as God, and additionally, others dismissed it completely as an optional path because of the presentation of iśvarapranidhāna ${ }^{2}$ in the first chapter of the Yogasütra and completely ignored its involvement in the second chapter. The more objective scholars are on the topic, the more reluctant they seem to make a definite conclusion. Even though some scholars attempt to stay true to the ontology Patañjali's Yogasūtra follow, nevertheless they contribute to the obscurity of the identity and nature of the term iśvara by continuing to use the terms 'God' or 'Lord' as a suitable translation. Thus, my motivation for the present study arises from my frustration in attempting to find an answer to the following questions: Who is iśvara? What is Yoga? And how does the definition of these two relate to each other? It is my sincere hope to be able to shed some light on this topic through a new perspective in the hermeneutics of Classical Yoga.

\footnotetext{
${ }^{2}$ While these terms and concepts will be explored further throughout this study, particularly in Chapter 5, $\bar{\imath}$ 'svarapranidhāna is presented in the first chapter of the Yogasūtra in sütra I.23 as íśvarapranidhānadvā (ìśvara + pranidhāna $+v \bar{a}$ ). The word $v \bar{a}$ is translated to 'or', which is a possible reason why it is sometimes interpreted as an alternative to other methods. However, this is only valid if the first chapter is isolated from the rest of the text, since ìśvarapraṇidhāna is foundational to kriyāyoga and Aștanga Yoga, presented in the second chapter, therefore, it should not be completely dismissed as an optional path. As this analysis will demonstrate, it is rather a functional method within the system of Patañjali Yoga.
} 


\section{CHAPTER 1}

\section{INTRODUCTION}

\section{Classical Yoga: The Yogasūtra of Patañjali}

In many cases, and certainly most popularly, the term Yoga, deriving from the Sanskrit verb root ' $y u j$ ', meaning to yoke, has been translated as union. This translation prompts the need to define what is being joined, and hence how that definition of Yoga relates to the Yogasutra of Patañjali and the path it propounds. Therefore, the primary motivation for the present study arises from the deceptively simple question: "what is Yoga'? And how and to what extent the understanding of the term iśvara in the Yogasūtra is a determinant of such definition. In an attempt to define Yoga, ${ }^{3}$ it considers two opposing definitions: Yoga as 'union' and Yoga as 'harnessing', since the definition of the term would be directly related to the goal the system it comes to represent. Given the ambiguity of the term iśvara, its interpretation and translation would come to directly affect both the path and the ontology of Classical Yoga, as well as the interpretation and thus the understanding of the term Yoga itself.

The Yogasutra is a work attributed to the Sage Patañjali, who, while his identity is not entirely clear, is understood to not have been the creator of the system of Yoga, but rather a compiler of an older system, or possibly a collection of different Yoga techniques. The identity of Patañjali as well as the date of the text are both uncertain.

\footnotetext{
${ }^{3}$ Yoga. m. Vyuj - "the act of yoking, joining, attaching, harnessing, putting to (of horses)... selfconcentration, abstract meditation, and mental abstraction practiced as a system (as taught by Patañjali and called the Yoga philosophy)" (Monier William 856).
} 
While some attach him to mythological characters considering him to be the "incarnation of the thousand-headed serpent Ananta or Adiśeșa " (Burley 26), others have connected him with Patañjali "the grammarian and author of the Mahäbhāsya" (Müller 313), the great commentary on Pāṇini's work on Classical Sanskrit grammar, the Aștadhyāyȳ, thus placing the text around the second century BCE. "Scholars such as R. Garbe and S. N. Dasgupta maintain that the grammarian and the yoga writer are identical". On the other hand, others place it as late as 500CE; however, many agree "that the Yogasütra is a product of the second or third century CE" (Whicher, The Integrity of the Yoga Darśana 42).

Of all the different practices of Yoga that have existed, Patañjali's Yoga was considered to be the authoritative text to represent the system of Classical Yoga at the time the six Darśanas ${ }^{4}$ began to be categorized, most likely, because it is the most thorough text that devotes itself exclusively to the topic of the practice of Yoga. Furthermore, Patañjali "supplied Yoga with a reasonably homogenous framework that could stand up against the many rival traditions" (Whicher, The Integrity of the Yoga Darśana 43), as he had a greater focus on the practical application of the system rather that seeking to present a philosophical treatise in its own right. Instead of propounding a particular ontology in the text itself, Patañjali largely builds on the ontology of Classical Sāṃkhya, a system that has very often paired up with Classical Yoga as a consequence of their similar approaches.

\footnotetext{
${ }^{4}$ Darśana: A philosophical category of the Classical Hindu philosophy literally meaning 'to view or see'. The six categories or darśanas that together come to form Classical Hinduism are: Nyāya, Vaiśeșika, Sāṃkhya, Yoga, Pūrva Mīmāṃsā, and Uttara Mīmāṃsā.
} 
The Sāmphyakārikā of İ́varakṛṣna is regarded as the authoritative text of Classical Sāṃkhya, and "the earliest available text on the Sāṃkhya philosophy", considered to date at around the third century CE (Burley 16). While there is no known earlier Sāṃkhya text, it is generally assumed that the Sāmkhyakārikā draws from a much older source, since not only the Yoga system derived from its philosophy, but there is also a wide range of texts throughout history that have drawn upon its concepts. Proto-Sāṃkhya is an unorganized pre-philosophical tradition that traces back Sāṃhyan elements in other older texts, such as several major Upanișads and the Bhagavadgittā. While it is considered by many to come from an earlier theistic philosophy (Nicholson 74), this conclusion seems to derive from the interpretation of the texts where these elements appear, for since there is no older Sāmphya text, it is impossible to determine the meaning of those elements in their own right (Krishna 195). In this light, Proto-Sāṃkhya appears to be the remnants of an ancient philosophy from where other philosophies either built upon or borrowed from without necessarily implying a complete adherence of these to the full ontology of the ancient Sāmkhya, given there was ever such an organized system in the past.

The ontology of Classical Sāṃhya (Sāṃkhyakārikāa) is based on a dualistic model of "subject and object and which maintains that the fundamental error consists in their confusion or identification in any form or at any level" (Krishna 202). Sāṃkhya philosophy describes the universe to be made up of only two independent elements: purușa $^{5}$ and prakrti, ${ }^{6}$ which "are thus two ultimate, eternal and independent principles of

\footnotetext{
${ }^{5}$ Purușa is everything that prakrti is not. In contrast, it is the seer, or draștr, that which only has the ability of seeing, but not the quality of being seen.
} 
existence. Purușas are many, prakrti is one" (Tiamni 189). The present study will demonstrate that Patañjali makes very clear that these two elements exist independent from each other as well as the fact that there is not one purusa or transcendental reality but rather a multitude of seers ${ }^{7}$ in sütra 4.15: "In view of the multiplicity of consciousness [as opposed] to the singleness of a [perceived] object, both [belong to] separate levels [of existence]“ (Feurstein, The Yoga Sütra of Patañjali 134), as well as sütra 2.22, where he explains that even though the perception or experience of prakrti ceases to exist as such for the liberated seer, prakrti itself does not.

The Yogasütra of Patañjali, as the name implies, is a Yoga text written in sütra style. A sütra can be translated as 'thread'; it is a popular style of writing in India, used by several systems of thought, where the aphorisms are used as a mnemonic device in the memorization of a particular text. Thus, by definition, a sütra is concise and accurate, using the least amount of words possible in order to illustrate a particular point while maximizing the potential for expounding meaning. The Yogasütra uses nouns almost exclusively, and rarely uses verbs. Because of the style and structure of the sütras, they are mainly concerned with providing definitions, in many cases, in a very brief manner. The Yogasütra is comprised of 196 sütras or aphorisms, divided into four pādas, or chapters. The first chapter, samādhipāda, focuses on the different practices that lead to the attainment of samādhi. The second chapter, sādhanapāda, expands on several of

\footnotetext{
${ }^{6}$ Prakrti is everything material, even in its most subtle forms, consisting of elements and sense organs, and is for the sake of purușa's experience and transcendence.

7 Throughout the present analysis the word 'seer' will be used as a translation for puruṣa, not to be confused with the ṛ̦is, or 'ancient seers'.
} 
those practices and goes deeper into the nature of samāahi. The third chapter, vibhitipāda, focuses on the great powers that may arise in the path of Yoga, and the fourth and final chapter, kaivalyapāda, explores the nature of the journey towards kaivalya, the final stage of Yoga. The relationships between the different sütras are not always linear, are often interconnected, and thus, different connections and relationships within the text need to be considered.

\section{Defining İ́vara: A New Perspective in the Hermeneutics of Classical Yoga}

There are several issues that arise in the endeavor of textual interpretation; from language and translation, historical and cultural context, to interpretation and application, thus, it becomes impossible to fully determine the intention and purpose of the original author, as well as the interpreters of such text, for more often than not, interpretation can be aligned with an attempt to perpetuate tradition and power. In many instances, since many commentators, whether intentionally or not, tend to interpret texts in a way that their work supports either their own personal world-views, or the systems they subscribe to, a particular text can be interpreted in a myriad of ways depending on what aspect of the text the commentator chooses to focus on, and which aspects they choose to ignore. Hence, inaccurate interpretations, even of a single term within one text, can lead to the inaccurate interpretation of the essence of the text, and come to misrepresent an entire system of thought, as well as perpetuate the authority of the different allegiances of such commentators.

There are many words and concepts in the Sanskrit language that do not have a direct translation into English, thus in many instances, translations have been made in 
order to accommodate an author's particular point of view. Indologist Max Müller speaks of the importance of translation and interpretation in "Sacred Books of the East", stating that "we want to know the ancient religions such as they really were, not such as we wish they should have been" (Müller 636). Therefore, in cases where accuracy in translation is impossible to achieve, it becomes essential to work towards accurate interpretation, without making undue assumptions, and most importantly, without trying to fit foreign concepts into them in an attempt towards understanding.

The first problem that arises is the ambiguity of the term iśvara, for it has been used throughout history in different contexts and thus conveyed different meanings (see Chapter 4). While it becomes impossible to know the intention behind Patañjali's decision to use such an ambiguous term, it is possible to at least try to understand its different uses throughout history as an attempt to identify the common use of the term contemporary to Patañjali, in order to understand the context in which he used this term. The second problem is the theistic interpretation of the term leading to the translation of iśvara as God, which has more serious consequences (see page 10). Thirdly, the elevation of certain commentaries to be as authoritative, and in some instances, more authoritative than the original text, as in the case of Vyāsa's Yogabhāṣya (see Chapter 2), perpetuates certain trends as facts, when in reality, they are not part of the original text.

Out of the total 196 sütras, the term issvara appears in the following eight sütras, and out of those eight, after introducing iśsvara, four are dedicated to defining it:

\section{I.23 iśvarapranidhānadvā - presents the concept of iśvarapranidhāna}

\section{I.24 kleśakarmavipākāśayairaparāmrștah puruṣaviśeșa îśvarah - describes īśvara}

\section{I.25 tatra niratiśayam sarvajñabijam - describes îsvara}


I.26 pūrveșamapi guruḥ kālenānavacchedāt - describes ìśvara

I.27 tasya vācakah pranavah - describes ìśvara and the method of iśvarapranidhāna

II.1 tapaḥ svādhyāyeśvarapraṇidhānāni kriyāyogah - defines kriyāyoga

II.32 śaucasantoșatapaḥsvādhyāyeśvarapranidhānāni niyamāh - defines niyama

II.45 samādhisiddhirīśvarapranidhānāt - defines the effect of iśvarapranidhāna

Patañjali first introduces the term in sūtra I.23: iśvarapranidhānādvā, a concept which appears again in the second book of the Yogasütra, first in sütra II.1 as one of the three elements of kriyāyoga, and then in sütra II.32 as one of five elements of niyama, the second limb of Patañjali's eight-fold path. The term iśvarapranidhāna is a compound of the following two words:

iśvara

able to do, capable of, liable, exposed to, master, lord, prince, king, mistress, queen, husband, God, the Supreme Being, the Supreme Soul (ātman), Śiva, one of the Rudras, the god of love, of a prince (Monier Williams 171).

praṇidhānāt laying on, fixing, applying, access, entrance, exertion, endeavor, respectful conduct, attention paid to, profound religious meditation, abstract contemplation of, vehement desire, vow, prayer (Monier Williams 660).

Only after 'iśvara' and 'pranidhānāt' have been put together do they typically get translated as 'devotion to the Lord' or 'devotion to God', thus implying a theistic interpretation, rather than a more accurate representation of the functionality of the term within the system (explored further in Chapter 5). According to the following definition, theism is a "worldview that perceives the orders of existence (physical things, organisms, 
persons) as dependent for their being and continuance on one self-existent God, who alone is worthy of worship...Theists hold that God, transcendent creator of the orders, remains an indivisible unity as he sustains them in accordance with their capacities and his ultimate purposes" (Bertocci 9102). Such definition implies a God whose existence is independent from the realities and elements of the universe, as well as a creator and sustainer of everything that exists. However, the present study will demonstrate that in Classical Yoga, as in Sāṃkhya, creation "is from prakṛti [nature, the seen] alone without the assistance of any outside agency. The proximity of purușa [spirit, the seer] and prakrti is a sufficient condition for the evolution and involution of the world" (Rukmani, "God/Íśvara in Indian Philosophy" 134). Therefore, the usage of the terms in relation to the system of Yoga, 'God' and 'theism', are both deemed as misplaced and misleading, for they consequently come to affect, and in some instances define, the meaning of the text and the system as a whole.

The present study proposes that the frequent translation of the term iśvara as 'God' presents several problems: first of all, it does not accurately represent the intent of the use and purpose of the term iśvara as used in the Yogasütra, specifically obscuring the interpretation of issvarapranidhāna, a functional aspect of the system. Secondly, it has directly led to the common understanding of the main distinction between Sāmkhya and Yoga as the former being atheistic while the latter theistic, labels that come to misrepresent both systems. Lastly, it allows for the confusion regarding the path of Patañjali. It obscures this path of discrimination, separation, involution and isolation towards liberation, to a point where it can lend itself to be interpreted and accommodated to fit into other ideologies, thus enabling a syncretic trend that has led to the popular 
understanding of Yoga as 'union with the divine'. The present study describes Classical Yoga as an esoteric practice that follows a path of involution towards the pursuit of liberation; it does not seek a connection with an external reality but rather strives to separate from it. Thus, the root of the problem resides within the commentarial tradition: starting with the early theistic interpretation of the term iśvara which led to its translation as 'God', and the subsequent interpretation of its functionality within the system of Classical Yoga.

Because of many discrepancies and interpolations into the text, particularly regarding this issue, it becomes crucial to determine the identity and purpose of iśvara in order to fully understand Patañjali's system of Yoga, particularly in regards to iśvara's placement in the path of Yoga. The present study also attempts to answer the following questions: If iśvara is defined as an outside agent who has the power to actively get involved in the world and grant liberation to those who worship him, as some suggest, what is the purpose of the rest of his very elaborate system? Furthermore, if the path is understood as a means to interact and merge with an outside agent, which is a common theistic interpretation, would the meaning of the ultimate goal Patañjali describes, that of standing in isolation in one's own nature (YSI.3, YSIV.34), ${ }^{8}$ not become contradictory and ultimately obsolete?

The purpose of the present study is threefold: (1) to define the use of the concept of iśvara in the system of Classical Yoga as found in Patañjali's Yogasütra, (2) to determine the theistic/atheistic nature of the concept and therefore the system of Classical Yoga, and

\footnotetext{
${ }^{8}$ YS - yogasūtra (Patañjali)
} 
(3) to identify the nature of the circumstances that have led to the obscurity of this subject. The present study attempts to define the concept of iśvara in the context of the Yogasūtra of Patañjali, through the analysis of Patañjali's path, while attempting to identify the source of the many conflicting views regarding this issue. It does not seek to neither prove nor disprove the actual existence of God in any capacity, but rather focuses on the presence and relevance of theism within the path Patañjali proposes in his Yogasūtra.

The present study will follow a textual analysis of the Yogasūtra in its original Sanskrit in addition to its commentarial traditions, aiming to consider the commentaries independent of the original text in order to find the discrepancies between the core text and its commentaries, as well as analyze the commentarial works on the Yogasūtra in order to identify the hermeneutical trends that have led towards the discrepancies regarding the nature and purpose of iśvara. In turn, these hermeneutical trends will aid to establish the spectrum delineated by scholarship regarding the nature and purpose of iśvara within the Yogasutra of Patañjali, from utterly useless to predominantly essential, within which reside a multitude of competing theories, and further attempting to place iśvara in the appropriate space within this spectrum.

On the one extreme Garbe describes the purpose for the inclusion of the term iśvara in the Yogasütra to be an attempt by Patañjali to appeal to both the Vedic ${ }^{9}$ authorities and

\footnotetext{
${ }^{9}$ Vedic: of the Vedas. This study considers the Vedas to not extend beyond the Samhitas, or collections: Rgveda (oldest, chants), Sāmaveda and Yajurveda (Melodies and sacrificial formulas), Atharaveda (youngest). Some early sources consider only three Vedas, while some scholars consider the Upanișads to be part of the Vedas. Chapter 3 (p. 32) describes the development of Brahmanic (Vedic) and Sramanic traditions as parallel yet radically different.
} 
theistic popular beliefs ${ }^{10}$ (Feuerstein, Philosophy of Classical Yoga 3), thus making his system of Classical Yoga more appealing, as well as using this as an attempt to elevate Sāmkhya philosophy through its association with his Yoga system (Dasgupta, Yoga Philosophy in Relation to Other Systems 248). On the other extreme of the spectrum there are scholars such as Vijñānabhikṣu who refer to iśvara in terms of the highest God, Parameśvara, describing him as the one who is "able to change the world, to bring it into existence and to make it disappear, just by his desire". According to his definition iśvara is thus a creator, preserver and destroyer God (Rukmani, "Vijñānabhikṣu" 133), and moreover, the revealer of the Vedas.

Furthermore, many commentaries often diverge in their grammatical understandings of Patañjali's Yogasütra, which proves to be a very common trend, where Classical Yoga concepts are accommodated by the commentarial tradition with incompatible ideas, as an attempt to reconcile Yoga with other more prominent systems of thought. These inconsistencies can be seen as early as Vyāsa's Yogabhāssya, the first known commentary of the Yogasütra, with his doctrine of sattva, which is original to $V y \bar{a} s a$, and not to Patañjali, as is the understanding of subsequent commentators. This situation proves to be particularly problematic since the status of Vyāsa's commentary is elevated to the authority level of the original text, thus leading these interpolations to be perpetuated as fact often effecting modern scholarly understandings.

Therefore, the analysis of the present study will cover several levels of interpreting Patañjali's Yogasütras, and the different ways in which these interact. (1) Firstly, the

\footnotetext{
${ }^{10}$ Indigenous and/or popular traditions, mostly dealing with strong devotional practices.
} 
grammatical understanding of the original text, without the influence of the commentarial tradition. (2) The early commentarial tradition, Vyāsa's Yogabhāṣya. (3) The medieval commentaries of Vācaspatimiśra and Vijñānabhikṣu. (4) Modern indigenous scholarship, particularly the way in which Swami Vivekananda presented Hinduism to the West; elevating Vedānta as the main philosophy of Hinduism and adapting it for a Christian audience. (5) Modern Western scholarship, focusing on Orientalists such as Müller and Deussen. (6) Finally, contemporary scholarship, such as Larson and Feuerstein, among others, and their respective understanding of the text. Thus, the present study seeks to explore an issue that has been often neglected, and in many instances, approached with great misunderstanding and misplaced assumptions, in an attempt to present a new perspective in the hermeneutics of Classical Yoga.

\section{Description of Chapters}

Having stated and briefly explored the different issues that arise when attempting to define the term isśvara in Patañjali's Yogasūtra, the following chapters will delve deeper into the matter. The organization of the present study's chapters is as follows:

Chapter 2, "The Commentarial Tradition", is an analysis of the commentarial tradition of Classical Yoga, in an attempt to identify and categorize the different hermeneutical trends that have led to the obscurity of the subject, introducing prominent commentators and their trends in order to identify the different issues of translation and interpretation that arise from these.

Chapter 3, "Deconstructing Hinduism", as an expansion of Chapter 2, is an analysis of the underlying reasons for some of these hermeneutical trends, by placing Patañjali's 
Yogasütra in the general context of the development of Hinduism, as well as an attempt to understand the classification of Classical Yoga as a Hindu Darśana, along with its consequences.

Chapter 4, "The etymology of the term ísvara and its Pre-Classical History", is a survey of the pre-classical use of the term iśvara, tracing its origin and use in different Indian texts throughout history, from its use to denote a worldly lord, to its use as a personal God, as well as the influence of devotional sectarian practices that have contributed to its interpretation as God.

While it becomes impossible to know the intention behind Patañjali's decision to use such an ambiguous term, it is possible to attempt to understand the context in which he used it. Chapter 5, "The Path of Classical Yoga: Reading Patañjali without commentary", is the product of a grammatical analysis of Patañjali's Yogasütra without relying on the use of commentary, primarily focusing on the translation of the first chapter, samādhipāda, and a selection of sütras from the second chapter, sādhanapāda, as well as deeper grammatical analysis on the sütras that directly deal with the issue of iśvara, in order to understand Patañjali's path of Yoga independent of commentaries, and the role of iśvara in the system of Classical Yoga exclusively. It contrasts this interpretation with those of the commentarial tradition from Chapter 2, specifically addressing the issue of the identity of iśvara in the Yogasütra, as well as defining the functionality of $\bar{l}$ śvarapranidhāna in the path Patañjali proposes.

Finally, Chapter 6 is the conclusion of the present study, where the term iśvara emerges as the representation of an empirical concept and a functional component of the path of Yoga, rather than an ontological concept per se. Thus, much rather than being or 
representing God, and thus being the determinant for the system of Classical Yoga to be classified as theistic, iśvara represents the ultimate ideal of the goal of Yoga: a purușa that has never lost its identity to its misidentification with prakrti, and as such, it functions as a practical and experiential tool, by being an archetype of this ultimate reality, providing the yogi with a direct experience of purus a, where he is able to get a direct glimpse of its true nature. The role of iśvara is therefore akin to the instruction manual Patañjali presents: a series of practical tools that facilitate a series of experiences which lead towards an ultimate goal: kaivalya, or isolation of self. 


\section{CHAPTER 2}

\section{THE COMMENTARIAL TRADITION}

Although the sütra style presents sets of rules or philosophical points of views in a way which facilitates for strict memorization, thus preserving the identity and accuracy of a text, it comes along with a commentarial tradition that, while necessary for the understanding of the sütras, allows for interpretation - or a series of interpretations - that can at times depart far away from the original text and furthermore be taken as an authoritative text itself. As commentators attempt to reconcile the text they are commenting on with their other areas of studies as well as their own personal viewpoints and philosophical and/or religious beliefs, the product of these attempts is a new text that is taken as an authority in the field and thus used by subsequent commentators as an authoritative source for their own work, in many cases without questioning the motives behind the work of these previous commentators, contributing to the diluting of certain concepts as they perpetuate conflicting ideas and confusion. In most cases the end product is an authoritative work that is a commentary of a commentary of a commentary; a work that is the result of an amalgamation of conflicting ideologies borrowed from other schools of thought which yet leaves no specific trace of their origin and the reasons for having been included in such a way, thus leaving the only conclusion of being an attempt at reconciliation due to the commentators' own personal motives.

Chapter 2 is an analysis of the hermeneutics of Classical Yoga, focusing on the identity, purpose and use of the term ìsvara in Patañjali’s Yogasūtra, from translation and interpretation of the term itself, as well as the commentators' theistic/atheistic 
classification of the text as a whole. It attempts to identify and categorize the different hermeneutical trends that have led towards the discrepancies regarding the nature and purpose of iśvara, covering the different categories of interpreting Patañjali's Yogasūtra, and the different ways in which these interact both between each other, as well as with the original text. The chapter addresses two of the main issues that arise in the endeavor of textual interpretation described in Chapter 1: firstly, the theistic interpretation of the term leading to the translation of iśvara as God, and secondly, the elevation of certain commentaries to be as authoritative, and in some instances, more authoritative than the original text, as in the case of Vyāsa's Yogabhāsya.

The Commentarial tradition of Classical Yoga can be divided into 5 different categories, according to time period and geographical location. (1) The early commentarial tradition, dating back to the $7-8^{\text {th }}$ century CE (Woods $\mathrm{xx}$ ), with the first commentary of the Yogasūtra, Vyāsa's Yogabhāṣya. (2) The medieval commentaries of Vācaspatimiśra's Tattvavaiśăradī of the $9^{\text {th }}$ century CE (Woods xxi) and Vijñānabhikṣu's Yogavārttika of the $16^{\text {th }}$ century CE (Rukmani, "Yogavārttika of Vijñānabhikșu" 3). (4) Modern indigenous scholarship, of the late $19^{\text {th }}$ century to early $20^{\text {th }}$ century CE, with the works of Dasgupta and Radhakrishnan. (5) Modern Western scholarship, focusing on Orientalists such as Müller, Deussen and Garbe. (6) Finally, contemporary scholarship, such as Eliade, Larson and Feuerstein, among others. While each author has, for the most part, a particular position on the issue of issvara, there are certain trends that are particularly prevalent to certain time periods and locations. The underlying causes for these trends will be addressed in Chapter 3, as it becomes necessary to place the text in the context of Classical Hinduism, and its categorization as a Hindu Darśana, for the 
present study argues that some of these trends are directly related to the distinction between Classical yoga and its 'partner' Darśana, Sāṃkhya, as the former being theistic and the later atheistic.

\section{Vyāsa's Doctrine of Sattva}

One of the elements not obviously defined by Patañjali is the degree of activity and involvement of iśvara in the yogi's path towards realization. If ísvara is a puruṣa (I.24), and thus by definition inactive within prakrti (Majumdar 52), in which way or form does he indeed "favor" the yogi due to "[this yogin's] profound-desire" (Vyāsa qtd. in Woods 48)? Vyāsa's attempt to solve this problem, which was fully accepted and supported by Vācaspatimiśra and Vijñānabhikṣu, is by explaining that iśvara, "by its own nature, cannot intervene in the spatio-temporal processes of Nature", therefore, he must acquire "a medium through which He can exert his influence": perfect sattva" (Feuerstein, "The Concept of God in Classical Yoga" 386). Vyāsa thus considers ìśvara to be "a special kind of Self" (Vyāsa qtd. in Woods 49) who is "at all times whatsoever liberated" (qtd. in Woods 50) and, "through his perfect sattvic state, active in the world as a remover of obstacles" (qtd. in Woods 62).

Vācaspatimiśra presents a yet stronger Brahmanic ${ }^{12}$ position than Vyāsa, as he legitimizes the omniscience of iśvara by the authoritativeness of the Vedas, and

\footnotetext{
${ }^{11}$ Sattva: Prakrti or nature is made of the interaction between three qualities or gunas: Sattva, rajas, and tamas. Sattva "connotes the bright, light, buoyant, wise, good, transparent aspects of nature" (Potter 3709).

12 Brahmanic: of the Brahmins, or India's priestly [and highest] caste. A tradition that is rooted in the Vedas, and is characterized by being exoteric, this-worldly, and intensely ritualistic.
} 
delegitimizes the authoritativeness of other authors, such as the Buddha and the Sage Kāpila, by describing their work as "pseudo-sacred-words" and "deceitful", hence elevating the Brahmanic tradition as the only legitimate source of authority (Vācaspatimiśra qtd. in Woods 57). He not only agrees with the doctrine of sattva proposed by Vyāsa, stating that iśvara "reflects, and assumes a sattva of perfect quality" (qtd. in Woods 52), as well as the fact that the proof of iśvara's existence and ability to interact in this world to be his revelation of the śästras or "sacred books", "[which] are composed by the iśvara" (qtd. in Woods 53), but he further validates and strengthens these positions, clearly perceiving Vyāsa as the highest authority in understanding Patañjali's Yogasütra. He then sustains this point by going back around and stating that, since "there is no possibility of error or deceit" in a state of "perfect sattva", it "[then] is established that sacred books have their proof in the perfect quality of His sattva" (qtd. in Woods 54). Hence, he uses a circular argument in order to prove issvara's appropriation of sattva: the proof of iśvara's omniscience is in the infallibility of the śästras, and the authority of the śāstras is in the omniscience of iśvara. According to Dasgupta, Vyāsa had resorted to the śāstra argument as proof of iśvara's sattva due to the fact that he had no other way of substantiating his position, for his doctrine of sattva "had no place in the system" (Dasgupta, Yoga Philosophy in Relation to Other Systems of Indian Thought 249).

Feuerstein challenges Vyāsa's doctrine of sattva by asking: "If liberation signifies the unconditional transcendence of the sattva (together with all other qualities of Nature, and thus Nature itself), then, how can the Lord be perpetually associated with a sattva without forsaking his condition of Freedom?" (Feuerstein, "The Concept of God in 
Classical Yoga" 393). Unfortunately, he concludes there is no answer for this question. "Vyāsa's (YBh I.24) ${ }^{13}$ answer is a dogmatic assertion that the association of the Lord with a pure sattva is beginningless", Vācaspatimiśra (TV I.24) ${ }^{14}$ states "the perfect sattva of the Lord can neither be conceived nor inferred" and considers its proof to be the scriptures which he believes are revealed by iśvara himself, while "Bhoja (RM I.23) $)^{15}$ bluntly argues that one should not ask this question, because the logical problem involved is one of what we would call the chicken-and-egg variety" (Feuerstein, "The Concept of God in Classical Yoga" 394).

On the surface, Vyāsa's theory might be a viable solution to explain iśvara's activity in the world, however, it appears to be a pure fabrication, as it makes no reference to the original text, which he uses to prove his presentation of iśvara as an active and powerful agent in the evolution of both prakrti and man towards realization. As "the authorities of Classical Yoga ultimately make this doctrine a matter of belief" (Feuerstein, "The Concept of God in Classical Yoga" 394), it becomes clear from comparing the original text and Vyāsa's commentary that Vyāsa's doctrine of sattva, however a clever attempt to solve an important discrepancy, is original to Vyāsa, and not Patañjali. This distinction, however, is not implicitly made by neither Vyāsa or by subsequent commentators, and thus it is regarded as Vyāsa's clarification of Patañjali's work, rather than a doctrine that is exclusively original to him. Thus, Vyāsa's doctrine of

\footnotetext{
${ }^{13}$ YBh - yogabhāṣya (Vyāsa)

${ }^{14} \mathrm{TV}$ - tattvavaiśárad̄̄ (Vacaspatimiśra)

${ }^{15}$ RM - rājamārțāṇda (Bhoja)
} 
sattva has been used in subsequent commentaries as if it was original to Patañjali, and as a consequence, perpetuated as fact.

\section{Vijñānabhikṣu's Syncretic Trend}

Vijñānabhikṣu is the most prominent exponent of the syncretic trend in the hermeneutics of Classical Yoga. A yogi at heart (Matilal 9595) at a time in which, "in the philosophical field, Vedānta ${ }^{16}$ was at its height and on the other hand, in the religious field, Bhakti was gaining supremacy", Vijñānabhikṣu attempts to reconcile his personal beliefs with the current trends "in order to establish Yoga in a Vedāntic [and Bhakta] atmosphere" (Rukmani, Yogavārttika of Vijñānabhikșu 8). He speaks of ìsvara in terms of the highest God, Parameśvara, stating that he "is able to change the world, to bring it into existence and to make it disappear, just by his desire". Iśvara in his view is thus a creator, preserver and destroyer God (Rukmani, "Vijñānabhikșu: A Maverick Philosopher" 133).

Rukmani does not consider Vijñānabhikṣu to be "faithful to the text he professes to comment on", for he is too intent in "conceding a bhakti viewpoint into the Yoga philosophy", going against the path Patañjali describes in the sütras themselves (further detailed in Chapter 5) as well as Vyāsa's commentary. He further attempts to substantiate his theistic and bhakti views by explaining "sütras I.23-24 in terms of how iśvara can bring about quickly asamprajñăta-yoga and kaivalya ${ }^{17}$ for the devotee who practices

\footnotetext{
${ }^{16}$ Vedānta: Veda + anta. Translates to End of the Vedas. Main collection of texts: Upanișads. As a Darśana: Uttara Mīmāṃsā.

17 Asamprajñāta-yoga and kaivalya: asamprajñāta is the highest form of samādhi before attaining
} 
bhakti"; elevating the functionality of iśvara in the text, through iśvarapranidhāna, as essential for achieving liberation (Rukmani, Yogavārttika of Vijñānabhikșu Vol.2 xi) and "emphatically dismisses Sāmkhya" and its position that "liberation (kaivalya) can be achieved through reasoning" (Rukmani, "Vijñānabhikșu: A Maverick Philosopher" 135). The result of his attempts to reconcile these different systems of thought ultimately misrepresents the Bhakti, Vedānta and Yoga traditions, for, Rukmani states, "in his hands Advaita Vedānta, Yoga, and Bhakti all get transformed" (Rukmani, "Vijñānabhikṣu: A Maverick Philosopher" 143).

Another important issue of interpretation is when a commentator presents conflicting views, either within the same publication or in their different works. This situation appears in many cases and at different levels. On the milder side, there are commentators, such as Feuerstein, who translate the term iśvara as 'Lord' yet speaks of him in theistic terms. Then there are those, such as Eliade, who actually use the term 'God' as a translation of iśvara, however giving the term God a new definition in this context that is more in line with the ontology the Yogasütra follows. On the most extreme cases, there are those, such as Dasgupta, who have complete contradictory views of the identity and purpose of iśvara in different publications.

Feuerstein, in spite of considering the common translation of iśvara by the "totally ambiguous word 'god"" as problematic, for the iśvara "is neither the creator, upholder or destroyer of the universe, nor is he judge over good and evil, right and wrong, nor supreme arbiter of human fates" (Feuerstein, The Yoga Sütra of Patañjali xi), his choice

kaivalya, or isolation of self, the goal of Patañjala Yoga. 
of language is not always in line with this statement. For example, when speaking of samprajñäta samādhi described in YS I.17, Feuerstein states that the cittavrttinirodah (cessation of mind processes) is not enough to attain this level of samādhi, supporting his argument with sütra II.45, samādhisiddhirissvarapranidhānāt (perfection of samādhi comes from iśvarapranidhāna), taken out of context, and declaring: "It appears that the 'grace' of the 'lord' (íśvara) is also required" (Feuerstein, The Yogasütra of Patañjali 37). His choice and use of the words 'grace' and 'lord' in this context appear to have a very theistic, and rather Christian tone.

Eliade states íśvara "is not a creator god, for the cosmos, life, and humanity proceed from the primordial substance, prakrti". For him, iśvara "plays a rather minor role" as an alternative path for "devotional yogins" (YS I.23). Despite his new definition of the term God, Eliade uses the term God as a translation for iśvara (Eliade, "Yoga" 9896). This proves to be very confusing for those readers who have a preconceived idea of the meaning of God. The introduction of a new and different definition for the term 'God' does not suffice in redefining the understanding of a word loaded with a very specific meaning for such a large population.

Dasgupta presents very different views regarding the nature and purpose of iśvara in three different books. In Yoga Philosophy in Relation to Other Systems of Indian Thought Dasgupta does not portray iśvara as a necessary intelligence for the functioning of prakrti, stating that the mere proximity of purușa to prakrti is enough to spark and sustain evolution, and the doctrine of karma being enough to sustain order in the world (Dasgupta 235-236). As iśvara does not quite fit "its system of metaphysics" it is "but loosely introduced, more as a matter of traditional faith than as having a place in the 
system of philosophy. $\mathrm{He}$ is introduced as only one of the alternative objects of concentration", albeit an object of superior importance over all others, for iśvara can "remove the obstacles and make the attainment of the goal of the yogin much easier" (Dasgupta 246).

In A History of Indian Philosophy, Dasgupta portrays a much more active íśvara, as an "intelligent Being who should help the course of evolution" (Dasgupta 260). He does not consider iśvara to be the creator of prakrti but rather a puruṣa himself, although one who is able to disturb "the equilibrium of the prakrti", whose by his "permanent will... the gunas follow naturally an intelligent course of evolution for the service of the best interests of the purușas". Furthermore, this iśvara helps prakrti "to follow an intelligent order by which the fruits of karma are properly distributed and the order of the world is brought about" (Dasgupta 260). Thus iśvara here is not only the initial trigger of evolution but fully active in the world, the one who controls the order of the gunas and the distribution of the "fruits of karma".

In Yoga as philosophy and Religion he begins to use the terms iśvara and God interchangeably. He does acknowledge "that the Bhāssya $a^{18}$ or the sütras [do not] ever mention Him as having anything to do with the controlling of the modifications of the prakrti by removing the barriers", but he states, "all the latter commentators agree in holding him responsible for the removal of all barriers in the way of prakrti's development" (Dasgupta 87). While he states that "it is on account of God that we can do good or bad actions and thus acquire merit or demerit", on the very next line he

18 Bhāṣya: commentary. 
continues: "Of course God is not active and cannot cause any motion in prakrti" (Dasgupta 87). He concludes that somehow he accomplishes this "in such a way that he stands ultimately responsible for the removal of all obstacles" in the development of both prakrti and man, so that perhaps he is not fully active, but can somehow have an effect in the world (Dasgupta 88).

Ultimately, in his "God in Yoga" chapter, he presents Yoga as karmayoga, jūannayoga, and bhaktiyoga, ${ }^{19}$ the last of which he declares to be the "easiest means of attaining salvation" (Dasgupta, Yoga as Philosophy and Religion 159). In this book he presents a fully theistic and Vedic notion of iśvara, as the source of the Vedas and able to preside over the laws of karma, and who, "just as a king, ...punishes or rewards people as they deserve" (160). He further interprets îsvarapraṇidhāna in full bhakti style: "By devotion (bhakti) iśvara is drawn towards the devotee ... and by his grace he removes all obstructions of illness, etc ... So for a person who can love or adore iśvara, this is the easiest course of attaining samādhi" (161). It thus becomes impossible to fully comprehend Dasgupta's point of view regarding the identity of iśvara, for it is ever changing.

\section{Issues with the Functionality of İ́varapraṇidhāna}

When coming at odds with attempting to reconcile a theistic interpretation of iśvarapranidhāna with a strict dualistic ontology, some scholars, such as Garbe, have simply attempted to either downplay iśvara's role or make away with the extent of

\footnotetext{
${ }^{19}$ The Bhagavadgìtā describes Yoga as being of three types: karmayoga, jñānayoga, and bhaktiyoga.
} 
iśvara's functionality in the Yoga system entirely. Garbe considers iśvara to have been included by Patañjali in order to appease the Vedic authorities and elevate his work in an atmosphere where theism prevailed. (Garbe, "Outlines of a History of Indian Philosophy" 588). For Zaehner, iśvara appears as a disposable aid in the yogi's path, having been introduced "for no other purpose than to help the soul towards isolation", most likely being "borrowed from one of the current theistic systems", once "this purpose has been served, the God is discarded and the yogin passes beyond him to the real business of mental concentration, the achievement of kaivalya or "isolation"' (Zaehner 127). Rukmani considers iśvara to be "only one among many supports in meditation", having "been accommodated in a backhanded manner into Yoga philosophy by Patañjali", for it does not seem to be compatible with the rest of the system (Rukmani, "God/İśvara in Indian Philosophy" 134).

Müller states that Patañjali's use of the term iśvara was not such a source of debate in the past, or at least there is no evidence in there being a philosophical debate on the matter (Müller, The Six Systems of Indian Philosophy 319). He considers iśvarapranidhāna to be an optional path (Müller, The Six Systems of Yoga Philosophy 308), and the inclusion of term iśvara in Patañjali's Yogasūtra to not necessarily be a determinant in qualifying the whole text as theistic, as he defines iśvara as "originally no more than one of the many souls, or rather Selves or Purusas, but one that has never been associated with or implicated in metempsychosis, supreme in every sense, yet of the same kind as all other Purușas. The idea of other Purușas obtaining union with him could therefore never have entered Patañjali's head". According to Müller, "the highest object 
of the yogin was freedom, aloneness, aloofness, or self-centeredness" (Müller, The Six Systems of Yoga Philosophy 325).

Yet, iśvarapranidhāna is not mentioned only once, but in three different places in the text: first introduced as an alternate path of meditation in YSI.23, then as one of the three elements of kriyanyoga in YSII.1, and lastly as one of the five niyama, or observances of aștangayoga in YSII.32 and YSII.45. It is not mentioned loosely in three places, but rather as part of three different paths the Yogasütra puts forward. Although it seems more manageable to label iśvara as not a relevant or important part of the Yoga system, this proves to be as much a fabrication and as inaccurate and misleading as considering iśvara to be synonymous with God or Brahman. This, most likely, is the result of a reaction to both a strong syncretic and theistic trend, both of which have been present, to a certain extent, since the time of Vyāsa.

While some commentators attempt to define iśvara as a philosophical concept and its placement in the Yoga ontology, others have focused on the more practical aspects of the concept. According to Burley, Patañjali's very definition of iśvara as a "'special self' (purușa-viśeșa) is crucial, as it implies that iśvara is not to be regarded as constituting a distinct ontological category" (Burley 50), but rather in the experiential realm (Feurstein, Classical Yoga 3). "Considering the distinctly pragmatic orientation of his Yoga", (Whicher, The Integrity of the Yoga Darśana 84) Patañjali must have included the concept of iśvara in his work because, according to Eliade, "iśvara corresponded to an experiential reality" resulting from a long tradition of yogic techniques. Thus, iśvara represents the ideal for the yogi to reach, "an archetype of the yogin - a macroyogin", whose concept might have been inherited from his position as "a patron of certain yogic 
sects" (Eliade, Yoga 75). Thus, according to Whicher "iśvara might have met primarily psychological and pedagogical needs rather than providing a purely ontological category" (Whicher, The Integrity of the Yoga Darśana 85).

\section{Conclusion}

The conflicting variety of not only different translations and interpretations but different approaches to defining the term iśvara as well as its placement and function within the Yoga system has, on the one hand, contributed to the many misconceptions on the subject, since, without much further and deeper investigation, and a full understanding of the system as a whole, it can lend itself to people picking and choosing whatever views are in agreement with their own. On the other hand, it is a testimony of the wealth of the commentarial tradition of Classical Yoga, one which, by attempting to peel away the layers of intentions, traditions and allegiances, is available to potentially illuminate on the subject rather than obscure it. 


\section{CHAPTER 3}

\section{DECONSTRUCTING HINDUISM}

The very nature of the sütra style of writing prompts a dependency on commentary which, while at times can be enlightening, in many cases, it can depart so far away from the original text that it creates a series of contradictions and discrepancies that further obscure the essence of its meaning. Since the many approaches and discrepancies regarding the identity and purpose of the term ìsvara in Patañjali's Yogasütra are not arbitrary, it is not only important to understand its nature and functionality within the constraints of the original text (see Chapter 5), but it also becomes imperative to identify the circumstances that have led to the numerous approaches and discrepancies that have contributed to the obscurity of this topic.

After reviewing the commentarial tradition of Classical Yoga and the most prominent hermeneutical trends that arise from them in the previous Chapter, the next step in this analysis is to place both philosophy and term within the context of the development of Hinduism, as well as attempting to understand the underlying meaning of the classification of Classical Yoga as a Hindu Darśana, along with its consequences. Hence, Chapter 3, as an expansion of Chapter 2, is an analysis of the underlying reasons for some of the hermeneutical trends that have led towards the discrepancies regarding the nature and purpose of iśvara, in order to fully understand them, instead of simply dismissing certain interpretations and labeling as incorrect.

The catalyst for the syncretic trend that plays an essential role in the misrepresentation of Patañjali's path of Yoga is a homogenizing trend that primarily 
arises from a necessity to perpetuate Vedic authority that starts as a reaction against the rise of the Upanișadic movement. Further, this homogenizing trend is then continued by the need to categorize Hinduism into a cohesive system with agreeable components, arising from the necessity to organize against the rise of traditions, such as Jainism, but particularly Buddhism, that vehemently denied the authority of the Vedas. This gave birth to the ambiguous categorization of the astikas and the nāstikas, the agreers and the deniers, which are directly tied to the emergence of the six Darśanas, or orthodox systems of though, as the philosophies that constitute Classical Hinduism. This homogenizing trend is further strengthened by the desire to elevate Hinduism as a world religion as a reaction against the negative depiction of Hindu traditions by Christian missionaries during the British colonialism of India, which, further strengthens Vedic authority and ultimately legitimizes Hinduism as a world religion, finally emerging not only as a homogenous system but further presented, in many instances, as a monotheistic religion, and thus, elevated to the authority of the Abrahamic religions.

While there are advocates of both sides of the spectrum, "the idea of Hindu unity is neither a timeless truth nor a fiction wholly invented by the British to regulate and control their colonial subjects", the later which is caused by "tendentious readings based on a modern tendency to homogenize and oversimplify pre-modern Indian history" (Nicholson 2). The present study agrees with the theory that the use of Hinduism as a religious term is not considered to have been in use until after India's medieval period (Nicholson 196). Hence, it is more aligned with the view that the homogenizing trend was an indigenous trend that developed slowly throughout centuries, and that eventually was perpetuated and strengthened as a reaction to foreign control and influences. 
“The word 'Hinduism' is loaded with historical and political resonances, ... with proponents and detractors, open to varied interpretations" (Nicholson 1), demonstrating to be much more complex than a religion or a set of philosophies. It is a multiplicity of intertwined world-views in constant interaction with each other, agreeing and disagreeing, approving and disproving. From exoteric rituals and esoteric practices, oral traditions and ancient texts, familial lineages and popular celebrations, all of these come together to form what has come to be labeled as Hinduism. From its heterogeneous nature arises the need to reconcile the different conflicting ideologies and practices that comprise it. While this approach is perfectly acceptable and understandable for someone's personal practice in order to form their own particular set of beliefs and world-views, in academia, it presents a very problematic situation. It thus becomes the scholar's responsibility to be able to understand different ideologies in their own right, abstaining as much as possible from the necessity to resolve the many differences that will arise, but rather being able to understand and embrace the uniqueness of the myriad of traditions.

\section{Brahmanism vs. Śramanism}

In spite of the many proposers of the concept that Modern Hinduism can be traced all the way back to the Vedas, and perhaps beyond, in an unbroken line of transmission, there is a clear divergence in the intention and practice between the Vedic and the Upanisadic traditions. From the two main classifications in the development of philosophy and religion in India, the former belongs to the Brahmanic tradition and the latter to the Śramanic tradition. Garbe considers Śramanic traditions to have developed 
parallel to the Brahmanic tradition in India "as lineages that, having begun with an individual or small group of philosopher-sages, then followed a line of descent running from guru to disciple. Over time, because a single teacher can have several disciples, a number of lineages would tend to develop", and as these were oral traditions, in time, they gave rise to a number of different systems of thought which held certain commonalities, such as Sāṃkhya, Yoga, Upanișads, and Buddhism (Burley 38).

The main general distinction between Brahmanic and Śramanic traditions is their contrasting paths and goals. The intention of Brahminic practices is focused on rituals for the maintenance of the order of the universe (rta) by sacrifice to the gods, as well as rituals that sought to maintain order within nature and society, being conducted and thus controlled by the Brahmin or priestly caste. "Centered around the household fire sacrifice" (Herman 52), this was a path towards prosperity, both material (food, wealth, etc) and immaterial (after life in Heaven - svārga) in this world (Herman 54), rather than a vehicle towards transcending it. Furthermore, the source of wisdom in the Brahmanic tradition is external, and thus 'heard', instead of realized.

Revelation in Hinduism is of two categories; śrūti and smṛti. Śruti is direct revelation, literally meaning 'heard' (Dhavamony, "Revelation in Hinduism" 163), while smrti is considered indirect or secondary, as it is revelation based on memory of śrutti (Dhavamony, "Revelation in Hinduism" 164). The Vedas are considered apaurușeya, or impersonal śrūti (Hiltebeitel 3994) as its wisdom was literally 'heard' by the ancient seers or rșis of India in the form of speech, or $V \bar{a} k$, and transmitted orally for centuries (Dhavamony, "Hindu Spirituality" 10). Thus revelation is of utmost importance, as it is considered to reveal truths that would be impossible to attain otherwise. Even though 
there are supernatural elements attributed to the rșis (Dhavamony, "Revelation in Hinduism" 166), they are not considered to be the authors of the Vedas, but rather passive transmitters of information (Watson 36). The revelation of the Vedas, therefore, is extrinsic to the rșis that received it, which, implied by the term śrutti (heard), came to them in the form of sound or words.

While the rșis are the witnesses or receptors of such revelation, the source is not always as clear as it is, for example, it the Abrahamic religions. At the time of the early Vedas the rșis did not seem to have a concept of a Supreme Being or creator. The gods and myths seem to arise from the minds of people who were in awe at the powers of the universe, who in an attempt to explain and control the world around them, "imagined that each of the great provinces of the universe was directed and animated by its own separate deity" (Muir 339). The gods were seen as personified representations of the powers of the universe, embodying the qualities of the elements they represented. The gods, as the rssis, are seen as intermediaries, albeit more powerful, between men and the underlying power of the universe.

In this passage from the Rgveda (10.129), known as the Hymn of creation, it is obvious that even then they did not fully understand the origin of the universe, nor did they attempt to reach a definite conclusion. There is an understanding, however, that the gods were not the creators, since they were created themselves after the creation of the universe, and furthermore, not capable to solve the mysteries of the universe.

There was neither nonentity nor entity; there was no atmosphere nor sky above... There were impregnating powers and mighty forces, a self-supporting principle beneath, and energy aloft. Who knows, who here can declare, whence has sprung, 
whence, this creation? The gods are subsequent to the formation of this [universe]; who then know hence it arose? From what this creation arose, and whether [any one] made it or not - He who in the highest heaven is its ruler, he verily knows, or [even] he does not know. (qtd. in Muir 345)

The second line suggests a very abstract conception of Brahman, a powerful energy that supports and sustains the universe. "The name 'Brahman' initially meant any sacred or magical formula. As time passed by, 'Brahman' came to be identified, not with the words or chants that conjured up the gods and their power but with the Power itself" (Herman 62). But the concept of Brahman as unattached from Vedic ritual is not fully developed until later, in the development of the Brāhmanas (Hiltebeitel 3991). The last line suggests that perhaps there is no creator; for if the highest God does not know about the origin of creation, creation could have preceded Him as well.

In many instances Brahman is translated as 'God', which can present as an obstacle in the search of a definition. Since many assumptions are made by the use of this word, the result can be of inaccuracy and confusion. In many instances Brahman is perceived as a deity, therefore, early Vedic religion is seen as polytheistic, being centered on a pantheon of anthropomorphic deities. In this view, the word 'God' for Brahman is easily confused with the word 'gods' for the deities. Also to be considered is the fact that in the Vedas, several different gods are regarded as the source of knowledge and creation. However, also found within the Vedas are statements that explain that in the end, all gods are the same, "They call him Indra, Mitra, Varuna, Agni; and (he is) the celestial wellwinged Garutmat. Sages name variously that which is but One" (Muir 342). 
In time, many of these early deities that the rșis received the śrüti from "would disappear eventually or take secondary place in the Hindu pantheon" (Dhavamony, "Revelation in Hinduism" 166). However, there is still a focus on their power and its ability to interact in the maintenance of the universe (Muir 341), which towards the later parts of the Rgveda allows the Brahmins to directly engage with that underlying energy or power during the action of ritual. This power behind all elements of the universe, that can be interacted with during Vedic ritual, begins to be identified independently from attachments, leading to be conceived as the Absolute. "Stripped of mythical and ritualistic elements, it becomes identified with the universal Self (Brahman) or the Absolute" (Dhavamony, "Revelation in Hinduism" 180). Thus "the stage was set for seeking solutions not by turning outwardly to the gods, whether with priestly help and sacrifices or not, but by turning within oneself to where Brahman resides" (Herman 64), beginning the transition from the exoteric practices of the Vedas towards the esoteric practices of the Upanișads.

With a clear shift from exoteric to esoteric practice and intention from the Vedas to the Upanișadic movement, the Bṛadäranyaka Upanișad, a transitional text between the Aranyakas and Upanișads, presents the intention of text as being very different from the Vedas: "Lead me from the unreal to the real. Lead me from darkness to light. Lead me from death to immortality" (Prabhavanada and Manchester 93). Long gone is the desire to connect with external gods and the need to control the world through ritual. The focus is internal, the intention individual, as the goal shifts from attaining prosperity in this world and ensuring after-life in svärga to transcending this world through self-realization 
and thus achieving liberation from the bondage of samsāra. It is thus a declaration for the quest towards knowledge, truth and liberation.

Some stories in the Upanisads illustrate a clear break from the authority of Brahminism. The following story questions the validity of the caste system as prescribed in the Rgveda. The significance of this is that as part of the Vedic dharma is questioned, it opens the possibility to question the whole of the Veda. In the Chandogya Upanisad there is the story of a young boy who asks his mother about his caste, as he wants to study the Vedas. His mother, who was a servant, tells her son to call himself by his given name, clearly stating the irrelevance of his caste. When the boy expresses his desire to study the Vedas to a teacher, he is questioned on his caste. The boy repeats what his mother told him, to which his teacher responds: "None but a true Brahmin would have spoken thus. Go and fetch the fuel, for I will teach you. You have not swerved from the truth" (Prabhavanada and Manchester 74-75). And so, the teacher accepts him as a student regardless of his non-Brahmin caste. Since caste is determined by birth, not by attitude or action, according to this view, acting as a Brahmin could lead to be accepted as one, presenting a clear break in tradition.

\section{The Caste System and the Monopoly of the Brahmins}

Since the concept of caste as it is deeply ingrained in Indian society and religion, it is therefore essential in understanding their development. The four basic castes or varnas, directly related to occupation and status, are inherited and permanent. These are the Brahmins, or priestly caste, the Kșatriya, or warrior caste, the Vaiśya, or merchant caste and the Śudra, or servant caste (Herman 52). There are also people who do not 
belong to any caste and are therefore considered to be lower than the Śudras; these as the non-caste and the untouchables. Throughout the years many have attempted to abolish the caste system, and while it has been possible to create some progress against the discrimination of the lower castes, the system itself still stands in India today. The caste system is so hard to dissolve mainly because of the fact that it is described in the Vedas as part of the dharma, or duty. As it is in the Vedas, and the Vedas are śrüti, as the Vedas are considered by many to be absolute truth, so is the concept and implementation of the caste system; hence observing the caste system is part of Vedic dharma.

The only caste that was allowed to learn and perform the various Vedic rituals was the Brahmin caste. Furthermore, only the next two lower castes, the Kșatriya and Vaiśya had access to the rituals through the Brahmins. The Śudra, the non-caste and the untouchables were not allowed to be part of the Vedic rituals at all (Herman 52). One of the problems this presents, is that a large number of the population had no access to any opportunity of prosperity, the other, is that the population that had access to it was forced to use the Brahmins as intermediaries. Considering the fact that the household rituals were intended for the assurance of prosperity, along with the fact that the Brahmins were the only vehicle towards such prosperity, the Brahmins came to be extremely powerful. "The religion became power oriented, excessively ritualistic, priest dominated and aristocratic" (Herman 63); the Brahmins were no longer just 'intermediaries', but rather the administrators and proprietors of the religion.

The attempt to preserve Brahmanic authority prompts a homogenizing trend in India that inspired the work of philosophers such as Vijñanabhikșu, who "claimed that, properly understood, Sāṃkhya, Yoga, Vedānta and Nyāya were in essence different 
aspects of a single, well-coordinated philosophical outlook", dismissing their abysmal differences as a mere "misunderstanding" (Nicholson 3). The Vedic samphitas, with the designation of śrūti, were of the highest authority since they were considered revelation. The authority of the Brahmins, as well as that of the samhitas, led to a tendency of connecting smrti works to the philosophy of the Vedas to be perceived as "an authoritative addition to the Vedas" in order to elevate the validity of the work (Minor 1). Furthermore, the Vedic solution against the perceived threat of the rise of the Upanisadic movement was to absorb the new movement into the Vedic canon, renaming it Vedānta, literally meaning the end of the Veda, hence reducing it to being commentaries on the Vedas, as opposed to being a movement in its own right, even though it clearly presents an opposingly different philosophy, world-view, purpose, and goal than those of the Vedas.

\section{The Six Darśanas Strengthening the Homogeneity Trend}

The homogenizing trend that arises from the need to reconcile the Vedic tradition and the Upanișadic movement in order to perpetuate Brahmin authority was further continued and strengthened when once again Vedic authority was questioned. "The age of the Buddha [563-483BC] represents the great springtide of philosophic spirit in India" (Radhakrishnan and Moore 349), as its propositions stimulated a dialogue between the many different existing philosophies that continued for centuries, and eventually gave rise to Classical Hinduism. As "the conservative schools were compelled to codify their views and set forth logical defenses for them, .... all logical attempts to gather the floating conceptions of the world into some great general ideas were regarded as darśanas. This 
conception led to the view that the apparently isolated and independent systems were really members of a larger historical plan” (Radhakrishnan and Moore 349).

The philosophies that are considered to recognize the validity of the Vedas are labeled āstika, or 'agreer', and are further categorized within the six Darśanas, or 'views', while those which are considered to not accept the Vedas are labeled as nāstika, or 'denier', and include Buddhism, Jainism and Cārvāka. Only after the late medieval period "it became almost universally accepted that there was a fixed group of Indian philosophies in basic agreement with one another and standing together against Buddhism and Jainism" (Nicholson 3). The reductionist and absolutistic categorization of multiple and widely different philosophies as 'āstika' inevitably implies a reference to Vedic authority, "falsely suggests a uniformity concerning the importance that was placed by Classical Indian philosophers upon one's attitude to Vedic authority, and serves to mask the diversity of philosophical positions within each of the broad religious categories" (Burley 2). Since "the acceptance of the Veda implies that all the systems have drawn from a common reservoir of thought" (Radhakrishnan and Moore 353), the emergence of the six Darśanas further strengthened the homogeneity trend.

Causing further problems is the translation of the terms asstika and nāstika as orthodox and heterodox, for they have come to be commonly known, in several instances, that what they agree with and deny is the existence of God. Therefore, it leads to the orthodox systems to be understood as theistic, allowing for the atheism of the unorthodox systems. Orthodoxy in this context does not mean the adherence to a particular doctrine such as the belief in God, but only focuses on the acceptance of the authority Vedas. Furthermore, "atheism in the Indian context does not carry with it irreligiousness. 
Atheism involves disbelief in a Creator, but is quite compatible with belief in salvation... Nor is it incompatible with prayer to the gods," for they are neither creator nor sustainers of the universe, and as human beings, bound to the reality of samsāra (Smart 23). Thus, the concepts of theism and atheism, in their definition and understanding in inevitable reference to the Western or Abrahamic concepts of religion, God, creation, and the universe, cannot fully apply to Indian systems, for these systems are simply too different.

The tendency to attempt to understand Indian religions through the lens of Christianity was first established by the early missionaries and the early Orientalists. "To the Westerner, however, the Oriental was always like some aspect of the West; he also seeks to convert each aspect of Oriental or Occidental life into an unmediated sign of one or the other geographical half" (Said 247). Therefore, the many Indian traditions that came to define Hinduism were interpreted through their comparison with Christianity, and under the constraints of the model the later had already established. This not only led to misinterpretations, but also to great generalizations, where single isolated elements were taken as the representative of the whole.

\section{Elevating Hinduism as a World Religion}

The desire to elevate Hinduism as a world religion as a reaction against the negative depiction of Hindu traditions by Christian Missionaries during the British colonialism of India further strengthens the homogenizing trend. The British Missionaries' depiction of the Hindus as "heathens" with "monstrous and ridiculous" gods, as well as their effort to convert and thus save them, prompted the Hindus to begin to present their beliefs in foreign terms, portraying Hinduism as a homogenous religion (Pennington 50). 
Furthermore, the British blamed the source for the inherent immorality of Hinduism, fueled by stories of violence, human sacrifice, idolatry, and obscenities, on their polytheism (Pennington 82), and hence established their superiority, as Christians, on their monotheism. Thus, the negative portrayal of the Hindus by the British Missionaries prompted their need to respond by presenting their religion in a cohesive and unified way, with one god and one collection of books, founded upon revelation, and as such, elevating their religion to the same authority level as the Abrahamic traditions. In time, the concept of Hinduism as a single system becomes accepted as it is established as a world religion, particularly after Swami Vivekananda's address in 1893 at the World's Parliament of Religions.

Swami Vivekananda is the foremost contributor to the propagation of Vedānta in the world. His teachings have had unprecedented effects both in the West and in India. By "planting the seeds of independent thinking and in creating a pride in India's past among the youth" (Rajamani 55), his mission elevated Hindu religion and society, having a direct impact on the Hindu Renaissance, eventually leading to the independence of India. He was able to present Hinduism to a Western audience not only in a way that they could understand, but most significantly, in a way they could come to embrace and eventually hold as their own.

Vivekananda presented Vedānta as 'the' Hindu religion (Vivekananda 1:387); a universal (Vivekananda 2:375) "religion of non-dual philosophy" (Vivekananda 1:502) that could be applied to any religion. In the West he preached monotheism (Vivekananda 1:331), barely used Sanskrit terminology, de-emphasized cultural remarks and furthermore translated concepts into a language adapted for Western Christians: using 
'God' or 'Father' instead of Brahman. Philip Goldberg sees this as "a conscious decision to emphasize a universal, adaptable Vedānta-yoga", by not openly disclosing beliefs and practices that could be perceived "as cultist or idolatrous" (Goldberg 80). In America Vivekananda never publicly mentioned the extent of his devotion to his guru and his status as an avatar, nor his guru's devotion to the goddess Käli. His success in this endeavor not only opened the doors for other gurus and thinkers, but also created a model that many have followed in adapting Eastern teachings for a Western culture.

\section{Conclusion}

The classification of Patañjali's Yoga as a Darśana does not come without a series of implications and consequences. It implies its affiliation into a cohesive and unified system of thought, its allegiance to the authority of the Vedas, and it defines itself as

distinct from those who are not considered asstika, drawing an alleged clear demarcation between itself and the nāstikas, when in reality, in many ways, "Yoga holds closer affinity with Jainism and Buddhism than with its Vedānta and Bhakti cousins" (Chapple, Yoga and the Luminous ix). Furthermore, its frequent paring with the system of Classical Sāṃkya, it allows for iśvara as the main distinction between the two systems, labeling the former as saiśvara and the later niriśsvara, which are often translated as theistic and atheistic, terms that come to misrepresent both systems. 


\section{CHAPTER 4}

\section{THE ETYMOLOGY OF THE TERM İŚVARA AND ITS PRE-CLASSICAL HISTORY}

The categorization of Classical Yoga as a theistic text is directly rooted in the consequences of the presence of the term ìsvara in Patañjali's Yogasūtra. Chapter 2 addresses the consequences that arise from certain prevalent hermeneutical trends that have led to the theistic interpretation of the term and the concomitant translation of iśvara as God. Furthermore, it reviews the commentarial tradition of Classical Yoga as well as the elevation of certain commentaries to be as authoritative, and in some instances, more authoritative than the original text, further perpetuating such misconceptions. Chapter 3 further expands on the nature of these trends, identifying them as consequences of an indigenous homogenizing trend that arose as a method to perpetuate Vedic authority and was perpetuated in order to elevate Hinduism as a world religion.

The third problem mentioned in Chapter 1 is the ambiguity of the term iśvara, for it has been used throughout history in different contexts and thus conveyed different meanings. However, the discrepancies in the understanding and application of the term are not exclusive to its use in different periods of time, but also prevalent in systems that are contemporary to each other. "Each system sets forth its special doctrine by using, with necessary modifications, the current language of the highest religious speculation" (Radhakrishnan and Moore 353). Hence, the different systems have used the most common philosophical terms, however, they do not necessarily use them with the same understanding, meaning, or in the same context. In order to demystify the term iśvara, Chapter 4 is an analysis of its etymology, primarily focusing on its pre-Classical history 
and development. Since in many cases the translation of iśvara as God is almost automatic, Chapter 4 is an exploration of the meaning of the term, tracing its development as far back as possible, from its secular origins and its transition from worldly lord to personal God. Further, it explores the concept of theism in Indian systems, its connection to the development of the term, and the Abrahamic influence on the interpretation and thus translation of Hindu terms.

In order to address the issue of terminology, an important distinction needs to be made between the following categories: (1) Functional deities, such as the Vedic gods Indra, Agni, Varuna, etc., who are individual, particular, and related to a specific aspect or activity of the universe. (2) Sectarian traditions, such as those focused on the worship of Viṣnu or Śiva, which have specific beliefs that are unique to their respective traditions, and that may vary from one tradition to another. (3) Widespread doctrines, such as the concepts of karma or moksa, which are concepts that have been generally accepted by the different Hindu traditions, whether they necessarily adhere to them or not. The development of the term iśvara will be traced from its Vedic origins, addressing the different stages in the understanding of the term and its use by different texts and systems of thought, as well as placing the term in the context of these three categories, and how these relate to theism in the development of Hindu thought.

The current most popular use of the term iśvara in Hindu thought is "in the sense of 'omnific, omnipresent Supreme God'. Excepting the sectarian words like 'Śiva', 'Viṣnu', 'Rāma', 'Kṛṣna', there is probably no other non-sectarian word which is so commonly used among the Hindus for the idea of God, as the word 'iśvara' (or 'Parameśvara')" (Shastri 487). However, the concept of Parameśvara in this sense did not exist until after 
the time of the Buddha (Shastri 498). This is precisely the position of M. D. Shastri, as he argues that, if the concept of iśvara in the sense of Parameśvara, a supreme and only creator God, had been established in India at the time of the Buddha, "the rise and great expansion of a godless system like Buddhism" would have been unattainable (Shastri 502).

\section{Secular Origins of the Term İśvara}

Examples of the secular origin of the term iśvara can be seen in the Astadhyāyzi of Pāṇini, the most authoritative work on Classical Sanskrit and the Mahābhāṣya of Patañjali (the grammarian), the great commentary on the former. In both cases the term "has been consistently used ... in the sense of a rājā or an administrative head" (Shastri 487). Furthermore, in the Mahābhāṣya 'the words 'rājāa', 'ina', and 'íśvara' are clearly regarded as synonyms and king Puṣyamitra is spoken of as "ísvara"' (Shastri 492), which clearly demonstrates the secular use of the term. Considering that Pānini's Aștadhyāyz "has been placed in the $5^{\text {th }}$ century BCE by some and in the $4^{\text {th }}$ century BCE by others" (Joshi 14), it would make the Aștadhyāyz contemporary to the time of the Buddha, as well as to at least some Upaniṣads, for the oldest are considered to be dated by Dāsgupta and Müller between the $6^{\text {th }}$ and $5^{\text {th }}$ century BCE (Joshi 13), and the earliest at around the $2^{\text {nd }}$ century BCE (Pflueger 4771). The Mahābhāşya however is considered to be dated around the $2^{\text {nd }}$ century BCE, therefore, at least until that time, there was no widespread understanding of iśvara in the sense of Parameśvara. 


\section{İśvara in the Vedas, Brähmanas, and Upaniṣads}

The term issvara first begins to be used in the Atharaveda, the youngest of the Vedic samhitas, in five passages; however, it is not used in the sense of Parameśvara, as it is "used only in the ordinary sense of a lord or master" (Shastri 489). In the Rgveda, the term does not appear at all, and only uses "the epithets $\overline{l s}^{\prime} \bar{a} n a$ or $\bar{\imath} s \bar{a}$ (from the same root) to designate the power of such deities as the universal sovereign Varuna, guardian of the cosmic order; Agni, the god of fire; Indra, lightning-hurling leader of the gods; and Purușa, the Cosmic Person" (Pflueger 4751). The term iśäna, a noun meaning "possessing, wealthy, reigning" and in its masculine form as "a ruler" or "master" (Monier Williams 171) appears 'in the Rgveda in the sense of 'a ruler' and is generally used for Indra and other gods" (Shastri 488). Furthermore, none of all these functional deities represent a highest God, since none of them seems to be consistently above the rest. Additionally, as illustrated in Chapter 3, the Rgveda takes a rather agnostic position regarding the nature of the creator of the universe, and further states the many deities are not the creators, for they were created after creation took place.

Throughout the Brāhmanas the god Prajāpati is elevated "as the embodiment of Vedic sacrifice" and begins to be connected to the Absolute Brahman (Pflueger 4751). However, the suffix pati in Prajapati is another word that has been used in earlier times in the sense of a lord which did not become as widespread as the terms derived from $i s$ (Gonda 133). In the ten older Upanișads, the term iśvara "not only has not been used in the sense of Parameśvara, but also, excepting the Brhadāranyaka Upaniṣad, it has not been used at all", the latter in which it is used in the sense of "capable of" (Shastri 494). The importance of the concept of Brahman arises in the Upanișads; however, it cannot be 
equated to the later understanding of Parameśvara, for the Vedāntic concept of Brahman does not imply an external worship of an external entity or being, as is the case with the devotional understanding of Parameśvara. In the Upanișads Brahman emerges as the Absolute; it is the subtle and the concrete, the big and the small, the in and the out, the Self and the Absolute.

In the Upanișads, the atman, or Self, is seen as the microcosm of Brahman. While atman is often times translated as soul, this is not the understanding that the Self is individual and particular of the person who embodies it. The misunderstanding that arises in the interpretation of Vedāntic doctrine from later devotional practices has led to the understanding that the Self searches to merge with Brahman. However, this is not the case, as the Self is not considered to be separate from Brahman, for Brahman and the Self are one and the same. The cognitive error in this case is due to the perception that they are separate, thus, the solution, and hence the goal of the system is the realization that the separation is an illusion; there is no merging, for they have always been one. Furthermore, Brahman was never really perceived as a popular deity: "The very fact that it is conceived in neuter gender shows that it can never be the object of popular worship. The god of popular worship is always conceived in masculine or feminine gender" (Shastri 497).

The Katha Upanisad describes the eternal qualities of Brahman in terms of the Self, illustrating their homogeny. Furthermore, it clearly states that Brahman "is neither the cause nor effect", for it is the Absolute, which is outside the Western understanding of God. 
It is - Om. This syllable is Brahman. ... The Self, whose symbol is $O m$, is the omniscient Lord. He is not born. He does not die. He is neither cause nor effect. This Ancient One in unborn, imperishable, eternal: though the body be destroyed, he is not killed (Prabhavanada and Manchester 8).

\section{From Worldly Lord to Parameśvara}

The transition of the understanding of issvara from worldly lord to the sense of Parameśvara begins with the rise of sectarian traditions as Vaiṣnavism and Śaivism, "which were occasioned by [the rise of] Buddhism" (Phillips 111). As a reaction to the Buddhist worship traditions that began after the death of the Buddha, the Brahmin trend of appropriating doctrines into their tradition in order to maintain their popularity and authority extended to them giving "prominence to the gods, Viṣnu and Siva" and "clustered around them in Epics and Purānas" (Phillips 46). It is only when the term iśäna begins to be identified as "a synonym of Śiva" that the transition of the term iśvara towards Parameśvara begins. "In the Śvetāśvatara and other older Śaiva Upaniṣads 'Maheśvara' and not 'iśvara' has been used for Śiva ... but gradually in the Śaivaite literature itself 'iśvara' came to be used for 'Maheśvara', and later in the tantras the term î́vara is used as a synonym of Śiva (Shastri 501).

The path of devotion, or bhakti, that arose in sectarian traditions and "percolated throughout India by the medieval period" (Siegel 422) "continues in the sectarian literature of the epics and Purānas, becoming from the medieval period to modern times the mainstream of Hindu spirituality" (Pflueger 4752). The devotional and thus exoteric understanding of iśvara in the sense of Parameśvara could not have become widespread 
until as early as the medieval period. As devotional traditions become increasingly popular it became necessary, in order to legitimize the devotional approach, to reconcile them with the most prominent $\bar{a} s t i k a$ systems, and thus connect them to Vedic authority. The need for reconciliation gave rise to a syncretic trend that has been perpetuated and popularized until contemporary times, its most prominent exponent being Vijñānabhikṣu, who "was active at a time when, on the one hand, in the philosophical field, Vedānta was at its height and on the other hand, in the religious field, Bhakti was gaining supremacy" (Rukmani, "Vijñānabhikṣu: A Maverick Philosopher" 8).

In his Yogavārttika Vijñānabhikṣu not only presents isśvara in the sense of Parameśvara as the efficient cause of the universe (Rukmani, "Vijñānabhikṣu: A Maverick Philosopher" 133), but he further considers iśvara to be able to "bring about quickly asamprajñăta-yoga and kaivalya for the devotee who practices bhakti" (Rukmani, "Vijñānabhikṣu: A Maverick Philosopher" 135), thus irrevocably redefining kaivalya in terms of its dependency on iśvara, thus elevating the devotional path. This understanding of iśvara is perpetuated by later commentaries such as Dasgupta's, as he not only considers devotion of iśvara to be "the easiest course of attaining samādhi", but he states that "by his grace he removes all obstructions" (Dasgupta, Yoga as Philosophy and Religion 161), making issvara an active agent in the path of the yogi towards kaivalya and thus elevating the role of iśvara in the path of Yoga even further. All of these understandings prove as a series of misplaced assumptions regarding Patañjali’s Yoga system. 


\section{Theism and Atheism in Indian Thought}

The bhakti tradition became increasingly widespread throughout India over time, and in the process, it intermingled with other prominent traditions, lead the masses to adopt a devotional approach towards several other sectarian traditions. This Hindu devotional approach, however, cannot be necessarily understood as theism in the same sense as the Abrahamic traditions. The following passage is a description of the syncretic approach common to Hindu practitioners as well as the incompatibility of Hindu thought with theism:

My own teacher in India is a devotee of Kṛṣna; he also practices Yoga, makes offerings to Agni, Ganeśa, Sarasvatī, and the lot, and without any feeling of contradiction speaks of samsāra as Brahman. He is, I believe, typical of Indian teachers when he asserts that there is really no difference between Śankara and Rāmānuja, between Śiva and Vișnu, between tantra and bhakti. Is he a theist? I would not dare ask him for the same reason that I would not dare wonder if Indian thinking is theistic (Siegel 420).

Theism, as stated previously, implies the belief in an entity who is the creator and sustainer of the universe, all-powerful, all knowing; "a god who is only one, only external, only distinct from his creation" (Siegel 420), which is not in line with Indian understandings of deity or creation. Furthermore, the concept of karma would make a complete contradiction to the Western concept of God, for in most Indian systems, karma has more power in affecting people's destinies than God, for the laws of karma cannot be broken, even by the most powerful deity (Garbe, "Outlines of a History of Indian Philosophy" 585). Since in India "God can be one and many, external and internal, even 
real and unreal" (Siegel 420), it is obvious that this understanding of God is completely different from the concept of God in the Abrahamic religions, therefore, the term theism would not accurately represent the complexity of the Hindu concept of deity, as it would be greatly misleading. In this line, the use of the term theism in Hindu thought would thus define the systems that do not adhere to the same beliefs as atheistic, leading to further misrepresentation and confusion, for the concept of atheism is vastly different in Hindu thought from Western thought. "Atheism in the Indian context does not carry with it irreligiousness. Atheism involves disbelief in a Creator, but is quite compatible with belief in salvation, ... [and] with prayer to the gods, conceived as beings who are inside, rather than transcendent to, the empirical cosmos" (Smart 23).

\section{Conclusion}

The development of the use of the term issvara is thus parallel to the development of the devotional approach in Hindu thought. The concept of creation takes an agnostic approach in the Vedas, with the appearance of functional and utilitarian deities yet no definite concept of creator or ultimate single sustainer of the universe. The concept of Brahman emerges as the Absolute during the Upaniṣads, which in time begins to be tied with sectarian devotional traditions that spread throughout India during the medieval period, giving rise to a pseudo-theism that has become a widespread doctrine of Modern Hinduism.

The term iśvara developed from the terms $\bar{i}^{s} \bar{a}$ and $i s \bar{a} n a$, which share the same verbal root, used in the earlier Vedas, while iśvara itself was not used until the latest of the Vedic Samhitas. However, none of these terms were used in the sense of 
Parameśvara, but rather in the sense of a worldly lord, which was a customary address for the many functional deities. The term was used as well in completely secular environments and contexts, as is the case with the Aștadhyāys of Pāninini and the Mahābhāṣya of Patañjali in the sense of rāja as an address to kings and worldly lords. Only when connected to Śaivism, which was a sectarian traditions at that time, does it begin to be used in the sense of Parameśvara, and only after the popularization of bhakti leading to the devotional approach to many other systems of thought becoming widespread does it not begin to be translated as God. This translation is further perpetuated in the face of Muslim and subsequent British invasions, as an attempt to legitimize the Hindu religion (Pennington 3).

In spite of the many efforts to elevate Hinduism as a world religion through attempting to filter and translate it into Abrahamic terms, Hindu traditions can and should be understood for what they truly are. Hence, this study proposes, in order to avoid further misunderstandings and confusion, that terms which are irrevocably tied to Abrahamic traditions not be used as suitable translations for Hindu terms, such as God or Lord for iśvara. The former has been established throughout the present study as misleading for several reasons, and the later has contributed to the understanding of iśvara as God due to its common use in Christian literature and popular parlance to denote God. Rather, it would lead to increased accuracy to retain the terms in their original Sanskrit, in the same way this has been done with terms such as Yoga, karma, and guru, so much so, that they have already become part of common parlance in the West. 


\section{CHAPTER 5}

\section{THE PATH OF CLASSICAL YOGA: READING PATAÑJALI WITHOUT COMMENTARY}

It has been previously stated that the frequent translation of the term ìsvara as God presents several problems: (1) it does not accurately represent the intent of the use and purpose of the term iśvara as used in the Yogasūtra, specifically obscuring the interpretation of iśvarapranidhāna, a functional aspect of the system. (2) It has directly led to the common understanding of the main distinction between Sāmkhya and Yoga as the former being atheistic while the latter theistic, labels that come to misrepresent both systems. (3) It allows for the confusion regarding the path of Patañali, obscuring this path of discrimination, separation, involution and isolation towards liberation, to a point where it can lend itself to be interpreted and accommodated to fit into other ideologies, thus enabling a syncretic trend that has led to the popular understanding of Yoga as 'union with the divine'. In order to address these issues most accurately, and particularly due to the ambiguity of the term as well as the inability to decipher with certainty the intention behind Patañjali's use of this term, it becomes imperative to understand its nature and functionality within the constraints of the original text.

Hence, Chapter 5 is the product of a grammatical analysis of the Yogasütra of Patañjali (starting on page 70) without relying on the interpretations presented by commentary, and the particular translation and interpretation of the text that arises from it. It focuses on the sütras that are most relevant in describing the path proposed by Patañjali, as well as the sütras that most illustrate the nature and functionality of the term 
iśvara. It is thus both a narrative of the path proposed by Patañjali, strictly based on the original text, as well as an analysis of the identity, purpose and use of the term iśvara and the functionality of the concept of iśvarapranidhāna within the Yogasūtra, and how these two relate to his proposed path as a whole, in order to clarify the aforementioned points.

\section{The Ontology of Classical Sāṃkhya}

The ontology of Classical Yoga, as that of Classical Sāmkhya (Sāṃkhyakārikā), is based on a dualistic model of "subject and object and which maintains that the fundamental error consists in their confusion or identification in any form or at any level" (Krishna 202). Sāmphya philosophy describes the universe to be made up of only two independent elements: purușa and prakrti, which "are thus two ultimate, eternal and independent principles of existence. Purușas are many, prakrti is one" (Tiamni 189). Patañjali makes very clear that these two elements exist independent from each other, as well as the fact that there is not one purușa or transcendental reality but rather a multitude of purusas or seers, and only one universal reality of nature, or prakrti. This is illustrated in sütra II.22, where he explains that even though the perception or experience of prakrti ceases to exist as such for the seer who has accomplished the aim of the path, prakrti itself does not, due to its universal nature, and to the multiplicity of purușas.

Parkrti is everything material, even in its most subtle forms, consisting of elements and sense organs, the latter that include the mind and thought processes, which are for the sake of purusa's experience and transcendence. Having the character of brightness (sattva), action (rajas), and inertia (tamas), these are further defined as its primary constituents, or gunas (see YSII.1). It is the seen, or driśya, which only has the quality of 
being seen, but not the ability to see. Purușa is everything that prakrti is not. In contrast, it is the seer, or drastrtr, that which only has the ability of seeing, but not the quality of being seen (see YSII.20). Due to their opposite characteristics they attract each other and interact, the purpose of that connection (samyoga) being the cultivation of the perception of the own nature (svarüpa) of the power (śakti) of both purușa (the owner) and prakrti (the owned) (see YSII.23). Furthermore, the existence of prakrti (the seen) is strictly for the purpose of purușa (the seer) (see YSII.21), in order for it to become established in its own nature (svarūpa) (see YSI.3), and thus achieving a state of Yoga (see YSI.2).

In a way, prakrti, like a body of water, becomes the mirror for purușa to see its reflection upon, which, due to its exclusive nature of seer, is unable to do on its own. In that process, purusa becomes so identified with its reflection, that it loses its identity completely as it becomes absorbed in its own reflection. This misperception (viparyaya) is identified by Patañjali as one of the five-fold fluctuations (vrttayah pañcatayyah) of the mind (see YSI.5), which is the mistaken knowledge (mithyāñjānam) on the foundation of an appearance that is not what it appears to be (see YSI.8). Hence, the main cognitive problem arises when, in the process of this interaction, which is supposed to illuminate the nature of both purușa and prakrti independently, puruṣa's misidentification with prakrti leads to puruṣa to lose the awareness of its own identity. Patañjali describes this misidentification as avidya, or ignorance (see YSII.24), and only through its destruction (abhāva), and thus the dissolution of that connection (samyoga) between purușa and prakrti, can the isolation of seeing (kaivalya) be achieved, which is the goal, ergo the end, of the path (see YSII.25). 


\section{The Path of Patañjala Yoga}

This isolation or abstraction of seeing (kaivalya) is the return to the original state (pratiprasava) of the primary constituents of nature (gunas), devoid of purpose for puruṣa (arthaśūnyānām), as well as the grounding (pratișthā) of puruṣa in its own nature (svarüpa) by this cultivated power of awareness (citiśakti) (see YSIV.34). Thus, the attainment of kaivalya is often times interpreted as liberation; however, while it is very appropriate to interpret it as such in terms of puruṣa having transcended its cognitive bond with prakrti, this does not necessarily imply any type of salvation or release from samsāara, or mokșa. Patañjali, in fact, ends his fourth and final chapter with this previous sütra (YSIV.34), and fails to elucidate further on what happens to the liberated puruṣa once kaivalya is attained. It appears that Patañjali describes kaivalya exclusively in terms of prakrti, as this is the realm where the practice takes place. Once transcended, perhaps it becomes impossible to describe its purușa experience or reality in prakrtic terms.

The solution Patañjali proposes, is that since a connection between puruṣa and prakrti has been established, puruṣa can use its transient prakrtic vehicle (body and mind) as a tool to follow a path of involution back towards the abstraction of purușa's nature, until that connection completely dissolves, and puruṣa can stand in its own nature (svarūpa) in a state of kaivalya. While Samādhipāda, the first chapter, describes the path in terms of samādhi, or mental concentration or absorption, Sädhanapāda, the second chapter, describes it more in terms of practice. Throughout the text, several techniques are discussed, in order to address the many different practitioners, with their different temperaments, who are in different stages of the path. At the beginning of the text, Patañjali defines Yoga as the restriction (nirodha) of the fluctuations of the mind 
(cittavrrtti) (see YSI.2), further describing the path and some of the techniques in terms of this definition. Further, he defines the result of the practice of Yoga as the establishment, or rather remaining (avasthānam), of the seer (drștu) in its own nature (see YSI.3), and the failure of achievement (itaratra), as the identification with those fluctuations (see YSI.4).

The first means towards the cessation of the fluctuations of the mind to achieve the goal of Yoga (YSI.2-3) is practice (abhyāsa) and dispassion (vairagya) (see YSI.12). From this definition, Patañjali begins to describe the different levels of commitment and intensity of practice and dispassion, as them being weak (mrdu), intermediate (madhya), and intense (adhimātra) (see YSI.22). While he describes dispassion as the conception (samjña) of the mastery (vaśîka ra) of being free from desire of that which is seen or heard (see YSI.15), the highest form of dispassion is the lack of desire for the constituents of nature (guna), or the non-attachment to prakrti (YSI.16). In the same way, in order for practice to become grounded (bhümi), it must be cultivated with reverence (satkāra), uninterruptedly (nairantarya), and for a long time (dīrgakāla) (see YSI.14). For those who have this highest level of commitment in their practice leading to its full establishment, and thus an intense desire of emancipation (tivvrasamvega), the goal of Yoga is near (see YSI.21). However, for those who do not, there are a series of alternatives, which are denoted by the word 'or' $(v \bar{a})$.

\section{İśvarapranidhāna as Concept and Method}

The first alternative he mentions is iśvarapranidhāna (YSI.23), after which he dedicated the following six sütras (YSI.24-29) to elucidate on that technique, defining its 
nature and its effects. After listing the obstacles (antarāya) (YSI.30-31), he prescribes the way to transcend them as the practice of a single reality (ekatattva) (see YSI.32), followed by the other alternative techniques: the retention of breath (YSI.34), the cognition of a sensory object that creates steadiness of mind (YSI.35), by engaging in activities that are sorrowless and illuminating (YSI.36), by directing the mind towards objects in order to transcend attachment (YSI.37), by cultivating knowledge in dreams and sleep (YSI.38), or, through dhyāna, meditation (YSI.39). The sequence of these seven alternatives to the intense commitment to practice and dispassion seem to follow a pattern of internalization, from the most external and concrete, the retention of breath, to the most internal and abstract, dhyāna. Therefore, at least in this chapter, iśvarapranidhāna appears to function as a starting point towards the process of internalization, leading to meditation (dhyāna).

However, this is not the only place in the text where iśvarapranidhāna is mentioned. While in Samādhipāda iśvarapranidhāna seems to be but on of several methods or approaches, in Sädhanapāda, the second chapter, it appears as one of the three elements of Kriyayoga, which is itself contained in the Niyamas, one of the elements of Asțtanga Yoga. Sädhanapāda in fact opens with the introduction of Kriyayoga, perhaps establishing its practice as an entry point to the techniques to follow, and defining it as being composed of three components: tapas, svādhyāya, and iśvarapranidhāna (see YSII.1). Further, it defines the purpose of its practice as leading towards the cultivation of samādhi and the attenuation of the afflictions or kleśa (YSII.2) (afflictions defined in YSII.3-10), and states the ultimate method for the eradication of the fluctuations (vrttaya) arising from such afflictions to be dhyāna, or meditation (see 
YSII.11). Further along the text, Patañjali introduces the concept of Aștanga Yoga, or the Eightfold Path of Yoga, as being for the cultivation of discernment (vivekakhyāti) (YSII.28). Kriyāyoga appears here again, contained within the second component of the path, Niyama, or restraints, along with two more components, purity (śauca) and contentment (santoșa) (see YSII.32). Here, he elaborates on the components of Kriyayoga: Tapas, or austerity, is the destruction of impurities, the perfection of the body (kāya) and sense organs (indriya) (see YSII.43), svädhyāya, or self study, is the means for a connection (samprayoga) ${ }^{20}$ to a chosen deity (iștadevatā) (see YSII.44), and iśvarapranidhāna, the means for the perfection (siddhi) of samādhi (see IYSI.45).

Up to this point, iśvarapraṇidhāna has been mentioned in two different chapters: in the first chapter as perhaps an optional method, and in the second chapter, as more of a foundational method of this path; however, wherever iśvarapraṇidhāna is mentioned, or whatever it is connected to, in all cases it leads to samādhi, specifically through dhyāna, or meditation. The term pranidhāna can mean 'attention', 'vehement desire', 'abstract contemplation', 'fixing', or 'vow'. However, in order to reach the most accurate translation of this word, it is necessary to trace the formation of the word pranidhanna to its smallest components: 'pra $+n i+d h \bar{a}+n a$ '. The verbal root $\sqrt{ } d h \bar{a}$ means 'placing', 'putting', or, 'holding', 'possessing', 'having'. When combined with the suffix ' $n a$ ' it

\footnotetext{
${ }^{20}$ Note the difference between Patañjali's choice of term here for the connection between a yogi and his iștadevata , and the term used for the connection between purușa and prakrti. In the former, he uses the term samprayoga, while in the latter, samyoga. The words are identical except for the prefix ' $p r a$ ' in the former. This can be understood as a deliberate choice by Patañjali in order to make a distinction between these two different types of connection. While the yogi requires action and effort (denoted by 'pra') in order to connect to its own concept of deity as part of a method towards concentration and thus internalization, the purușa does not strive to connect with prakrti, and thus, this connection can be understood as an unintended misidentification.
} 
comes to mean 'containing', 'holding', 'receptacle', or 'case'. So far, it can mean either 'placing' or 'holding' something somewhere, however, there is still the contribution of the prefixes ' $p r a$ ' and ' $n i$ ' in this construction to consider. The prefix ' $p r a$ ' as an adverb means 'forward', or 'forth', and as an adjective, 'like', or 'resembling'. First of all, whether in use as an adverb or adjective, 'pra' denotes an action, something that is performed. Adding the adverb 'ni', which can mean 'in', 'into', or 'within', adds yet another dimension to its meaning. Thus, when combined with the term iśvara, pranidhāna can be interpreted as the action of placing or holding forth into iśvara, or resembling what is contained or that which resides within issvara, the essence of iśvara.

\section{The Identity and Use of İśvara in the Yogasūtra}

After the introduction of iśvarapranidhāna, Patañjali describes iśvara as a special or distinct (viśeșa) purușa, its distinction resting on the fact that he is untouched by the accumulations of karma that arise from afflictions (kleśa) (see YSI.24), and in which the omniscient (sarvajña) seed (bijja) is unsurpassed (niratiśaya) (see YSI.25), as he is the teacher (guru) of the ancestors (pūrveșam) from not being limited (ānāvacchedāt) by time (kāla) (see YSI.26). The fact that iśvara is deemed a purușa means he is not outside the Sāṃkhya-Yoga model of duality, therefore, as a purușa, he is by definition a seer, a witness of the seen, or prakrti, and hence unable to interact with prakrti in a way in which he could have any effect or influence upon it. From Patañjali's definition, iśvara appears to be a representative of the highest ideal of the path, rather than an external

deity, and certainly, much different from a creator or sustainer God. Thus, by having included a definition of iśvara that contradicts the popular theistic meaning of the term, 
presents a possible deliberate intention of Patañjali to separate his use of the term from its use by other systems of thought or traditions (see Chapter 4 for the pre-classical history of the term iśvara).

Upon defining the identity of iśvara, Patañjali proceeds to explain the method of iśvarapranidhāna, as the recitation (japa) of the pranava (om), iśvara's sound (see YSI.27), which leads to the nature (artha) of essence or meditation (bhāvanā) (see YSI.28). This chanting or repetition (japa) of the pranava (om) serves a dual purpose. On the one hand, it is an abstract or vibrational representation of an ideal reality (iśvara), and on the other, it is a tool in this process of internalization, standing as a link, through action (chanting), between the conceptual iśvara and the fully internalized experience of transcendence. By being used as a point of focus, going beyond the identity of iśvara in worldly terms, using the pranava as an abstract representation of the archetype of the ultimate reality, through a process of internalization, from the japa or repetition, which represents a gross element or reality, to bhāvanā or essence/meditation, which represents a subtle or abstract element or reality, thus emerging as a deep empirical experience in the realm of meditation. As a result, the recitation of om allows the yogi to have an experience beyond body and mind, beyond prakrti: an experience of purușa itself. Meditating on iśvara, who is a purușa that has never lost its identity to prakrti, the pragmatic approach of Yoga allows the purușa to use iśvara as an alternate mirror, so to speak, in the process of bringing awareness back to an internal and subtle place, and eventually back to its true nature (svarūpa).

As far as Kriyāyoga, if Niyama is understood as a restraint, the question arises, what is it restraining? Patañjali defines the path of Astangayoga to be for the purpose of 
the cultivation of discernment, or vivekakhyāti, of the own identity of purușa from its misidentification with prakrti (YSII.28). The Niyama elements additional to Kriyāyoga, śauca and santoșa, establish a desire to protect one's body (svāingajugupsā) (YSII.40), a mastery (jaya) of the sense organs, one-pointedness (aikägrya) and right understanding (saumanasya) (YSII.41), as well as unsurpassed (anuttama) happiness (sukha) (YSII.42). These are further combined with the results from the practice of Kriyayoga: the destruction of impurities and the perfection of the body and sense organs through tapas (see YSII.43), the connection to a chosen deity (iștadevatā) through svādhyāya (see YSII.44), and the practice of iśvarapranidhāna as the means for the perfection of samädhi (see YSII.45). Clearly, the nature of these methods restrain the mind from engaging in further misidentifications, and hence in activities that lead away from the achievement of discernment (vivekakhyäti), as they support a self-centered, inwardminded approach. Even in the case of the use of iștadevatā through svädhyāya, since this is followed by iśvarapranidhāna, it can be understood as an external point of focus in order to achieve one-pointedness (aikägrya), and to be fully internalized through the practice of iśvarapranidhāna in order to cultivate right understanding (saumanasya).

Through the practice of iśvarapranidhāna, the yogi attempts to establish a connection with iśvara, yet iśvara here is not an external element or deity to worship, but rather a direct experience of purușa, where the yogi is able to get a direct glimpse of its true nature. In contrast, the concept of iștadevatā, presented by Patañjali as an element of svädhyāya, or self study, would function as an external deity, yet still, not one to worship particularly, but rather one to establish a connection or identification with (samprayoga) for the purpose of self study (see YSII.44). In this context, it seems the role of iśvara is 
described as a tool in the process of internalization necessary to fulfill this goal. If truth is to be defined as the closest approximation to a particular ultimate reality, in this sense, iśvara is proposed to be an archetype of this ultimate or rather ideal reality, which attainment is the goal of Yoga. The attainment of this reality does not imply going anywhere or merging with anything external, but rather realizing one's own nature. Thus, pranidhāna becomes more of a concept that aids in a process of internalization, or a transference of identity of the essence of iśvara with that of the yogi, which are the same in nature, puruṣa, rather than a seeking to attempt an external union or devotion.

\section{Classical Yoga vs. Vedānta}

From the present analysis, it thus becomes evident that the many common syncretic trends between Classical Yoga with other systems of thought, particularly those that lead to the popular understanding of Yoga as 'union with the divine', are nothing more than a misplaced reconciliation attempt, based on assumptions and interpretations that are in fundamental contradiction with the original text. The path Vedānta proposes is immensely different from that of Patañjali, as the nature of the cognitive error, as well as

the solution, are completely opposing concepts. In contrast with Classical Yoga and Sạmkhya, in the Upanișads there is only one element in the universe: Brahman; "incomprehensible, for it cannot be comprehended; un-decaying, for it never decays; unattached, for it never attaches itself; unfettered, for it is never bound" (Prabhavanada and Manchester 127). It is the subtle and the concrete, the big and the small, the in and the out, the Self and the Absolute. The attman, or Self, is seen as the microcosm of Brahman and not as a separate entity; therefore, Brahman and ätman are precisely one 
and the same. As in Classical Yoga, the error is due to avidyā, however, in Vedānta, the nature of this error is not due to a coming together, but rather a coming apart, when the ätman forgets its Brahmanic nature, as the fact that it and Brahman are one and the same.

If Vedānta were to be translated into Sāmkhyan terms, it could be said that there is only puruṣa, which is only one, and the illusion lies in perceiving prakrti as real as well as the separation between the many purușas as real. Realization then comes in realizing this illusion and uniting the seemingly separate and individual puruṣa with the one puruṣa that is eternally divine (Brahman). Since Sāmphya presents a dualistic model and Vedānta a non-dualistic model, the solution for the error in both systems is fundamentally different, thus their approaches towards liberation, completely opposite. 'Yoga', as a vehicle of correcting this primordial error, etymologically derives from the Sanskrit verb root ' $y u j$ ', meaning to yoke, can be defined as either joining or harnessing. In this light, while the term joining applies to Vedānta, the term harnessing would definitely be much more appropriate for Patañjali's Yoga. Therefore, "the fact that some interpreters have tried to read into them [Sāmkhyakārikā and Yogasūtra] both theism and Vedāntism... [is] a violation of the spirit of Sāṃhya as a distinctive philosophical position” (Krishna 198).

Íśvarapranidhāna as an external concept can be seen as a vehicle towards a process of abstraction that leads to the deep internalization of an experience of an ideal reality. If one mistakenly perceives the path as the goal, getting stuck on the vehicle rather than pursuing the destination, the destination will never be reached. Thus, the conception of connection with or worship of iśvara as the goal of Yoga would create a situation in which the path is mistaken for the goal, staying in the realm of devotion and eternally waiting to receive mokșa from iśvara, getting lost in the misidentification of the self with 
the path, creating attachment, and hence completely loosing the experiential nature of this path. Much like learning how to drive a car, once one achieves some basic competency in the activity, attachment is formed to the feeling of driving, and thus one begins to drive aimlessly for the sake of driving. Since for a beginner the goal of learning how to drive seems to be simply the ability to perform the act of driving, the more advanced driver should understand that learning how to drive is only a means to reach a destination. This logic would leave the one who did not, or perhaps could not go past the beginner stage, driving around in circles.

\section{The Concept of God in Patañjala Yoga}

In order to accommodate the concept of God into a strictly dualistic model such as that of Classical Sāṃkhya and Yoga, God would have to be either purușa or prakrti, as he cannot be both, and he cannot be neither, appearing as a distinct entity or reality, since there are no realities that exist outside or above purusa and prakrti. Even if it was said that there is a reality that exists above these two, such as is the position of some theistic commentators, "in either case the God is irrelevant from the perspective of salvation of the individual puruṣa" (Larson 237). Having established that iśvara, existing within the constraints of Sāṃkhya-Yoga's dualistic cosmology, is a purușa who has never been bound by prakrti, and that the path Patañjali proposes follows a path of involution towards isolation, it becomes evident not only that iśvara is not God, but that the existence or not existence of a theistic God is irrelevant in the path of Classical Yoga. According to G. M. Coleman, "Patañjali Yoga technique prescinds from whether someone admits a God or denies him" (qtd. in Feurstein, The philosophy of Classical 
Yoga 13). Larson considers the concept of a creator God to be irrelevant in the ontology of both Classical Yoga and Classical Sāṃkhya, and relates this to Sartre's position of theism regarding existentialism: "Existentialism is not an atheism in the sense that it would wear itself out in trying to demonstrate that God does not exist. It declares rather: even if God existed, that would change nothing" (qtd. in Larson 237). Whether issvara is perceived by some as an "inactive deity" (Deussen qtd. in Burley 39), the Supreme Creator Brahman (Vijñānabhikșu), or an experiential reality, since it is not a creator, nor sustainer, and has in fact, by definition, no means to function within prakrti, and thus has no role in the liberation of purusas, the existence or non-existence of a theistic God is utterly irrelevant in Classical Yoga.

\section{Sāṃkhya as Atheistic and Yoga as Theistic}

Another problem of the translation of the term iśvara as God in Patañjali's Yogasütra is the common understanding of the main distinction between Classical Sāṃkhya and Classical Yoga as the former being atheistic while the latter theistic, labels that come to misrepresent both systems. The only determinant leading to this labeling appears to be the either presence or absence of the term iśvara, as while the term does not appear in the Sämkhyakārikā, it does in the Yogasütra. Hence, in terms of the presence or absence of the term iśvara in the two different texts, Yoga has been labeled as saiśvara (with iśvara) and Sāṃkya as niriśsvara (without iśvara). Having established that Classical Yoga, following the same ontology as that of Sāmkhya, adheres to a strict dualistic model that could not possibly accommodate a theistic concept of God, their saiśvara and niriśvara classifications should not reflect their respective adherence to or 
rejection of a believe in God. While there is a difference between the two texts the systems which they represent, the nature of their distinction in terms of theism appears to be rooted in the mistranslation and misinterpretation of the term iśvara as God.

\section{Conclusion}

From the present analysis, the term iśvara and its functionality within the Yogasūtra, particularly pertaining to the concept of isśvarapranidhāna, emerges as the representation of an empirical concept and a functional component of the path of Yoga, rather than an ontological concept. Its functionality is defined by the experiential nature of the system itself, for it does not seek to present a philosophical point of view but rather presents a series of techniques to be used in order to achieve a series of experiences leading towards the ultimate goal of yoga, kaivalya or isolation in one's own nature. The role of iśvara is therefore akin to the instruction manual Patañjali presents: a series of practical tools that facilitate a series of internalizing experiences aimed at the attainment of an ultimate goal. Thus, much rather than being or representing God, and thus being the determinant for the system of Classical Yoga to be classified as theistic, î́vara represents the ultimate ideal of the goal of Yoga: a purusa that has never lost its identity to its misidentification with prakrti, and as such, it functions as a practical and experiential tool, by being an archetype of this ultimate reality, designed to aid the yogi in its path towards liberation. 


\title{
Grammatical Analysis
}

\author{
Key \\ m masculine \\ n neuter \\ f feminine \\ $\mathrm{p}$ pronoun \\ adj. adjective \\ adv. adverb \\ ind. indeclinable \\ sing. singular \\ dl. dual \\ pl. plural
}

\section{Nominal Cases}

1 subject

2 direct object

3 'by/with'

4 'to/for'

5 'from'

6 'of/'s'

7 'in/on/at' 
I $S A M \bar{A} D H I P \bar{A} D A$

I.1 atha yogānuśāsanam

now the instruction of yoga

atha 'now' ind.

yoga m(a)1 sing.

anuśāsanam 'instruction' $\quad \mathrm{n}(\mathrm{a}) 1$ sing.

\section{I.2 yogaścittavrttinorodhah}

yoga is cessation of the fluctuations of the mind

yoga

$\mathrm{m}(\mathrm{a}) 1 \mathrm{sing}$.

citta- 'mind, thought'

vrtti- 'turning, moving, existing'

cittavrtti- 'continuous course of thoughts'

norodhah 'process of ending' m(a)1sing.

\section{I.3 tadādraștu svarupe'vasthānam}

then the seer remains in its own nature

$\begin{array}{lll}\text { tadā } & \text { 'then' } & \text { ind. } \\ \text { drașțu } & \text { 'of the seer' } & \mathrm{m}(\mathrm{r}) 6 \operatorname{sing} . \\ \text { (draștr) } & \text { 'looker, one who sees' } \\ \text { sva- } & \text { 'own' } & \\ \text { rūpe- } & \text { 'in nature' } & \mathrm{m}(\mathrm{a}) 7 \mathrm{sing} . \\ \text { avasthānam } & \text { 'remaining' } & \mathrm{n}(\mathrm{a}) 1 \mathrm{sing} .\end{array}$




\section{I.4 vrtti sārūpyamitaratra}

elsewhere it remains identified with [those] fluctuations

vrtti-

sārüpya 'similarity, sameness in form' n(a)1sing.

itaratra 'elsewhere' ind.

I.5 vṛttayah pañcatayyah kliṣtālkiștāh

fluctuations are five-fold; obstructing and non-obstructing

$\begin{array}{lll}\text { vrttayah } & \text { plural of vrtti } & \mathrm{f}(\mathrm{i}) 1 \mathrm{pl} \text {. }\end{array}$

$\begin{array}{lll}\text { pañcatayyah- } \quad \text { 'five-fold' } & \mathrm{f}(\overline{\mathrm{i}}) 1 \mathrm{pl} .\end{array}$

klișta- obstructing'

akliștāh $\quad$ 'non-obstructing' $\quad \mathrm{f}(\mathrm{a}) 1 \mathrm{pl}$.

\section{I.6 pramānaviparyayavikalpanidrāsmrtayah}

[fluctuations are] evaluation, misperception, conceptualization, sleep, memory

pramāna- 'evaluation'

viparyaya- 'misperception'

vikalpa- 'conceptualization'

nidrā- $\quad$ 'sleep'

$\begin{array}{lll}\text { smrtayah 'memory' } & \mathrm{f}(\mathrm{i}) 1 \mathrm{pl} \text {. }\end{array}$

\section{I.7 pratyakșānumānāgamāḥ pramānāāni}

evaluation is direct perception, inference, testimony 


$\begin{array}{lll}\text { pratyakșa- } & \text { 'direct perception' } & \\ \text { anumāna- } & \text { 'inference' } & \\ \text { agamāh } & \text { 'testimony' } & \mathrm{m}(\mathrm{a}) 1 \mathrm{pl} . \\ \text { pramāṇāni } & \text { 'evaluation } & \mathrm{n}(\mathrm{a}) 1 \mathrm{pl} .\end{array}$

I.8 viparyayo mithyāñ̄ānamatadrupapratiștham

\begin{tabular}{|c|c|c|}
\hline viparyayah & 'misperception' & $m(a) 1$ sing. \\
\hline mithyā- & 'mistaken, false' & \\
\hline jñānam & 'knowledge' & $n$ (a) 1 sing. \\
\hline a-tad- & 'not that' & ind. \\
\hline rūpa- & 'appearance, form' & \\
\hline pratiștham & 'foundation' & $n$ (a) 1 sing. \\
\hline
\end{tabular}

\section{I.12 abhyāsa vairagyābhyām tannirodhah}

that cessation, is both practice and dispassion

abhyāsa- 'practice, vigilance of awareness'

vairagya 'by non attachment, dispassion' n(a)3dual

tad- 'that'

nirodhạ̣ 'cessation" m(a)1sing.

\section{I.13 tatrasthitau yatno 'bhyāsaḥ}

staying there [in its own nature] is the purpose of practice 


$\begin{array}{lll}\text { tatra- } & \text { 'there' } & \text { ind. } \\ \text { sthiti } & \text { 'staying in a particular condition' } & \mathrm{f}(\mathrm{i}) 7 \mathrm{sing} . \\ \text { yatna- } & \text { 'attempt, effort' } & \\ \text { abhyāsa } & \text { 'practice' } & \mathrm{m}(\mathrm{a}) 1 \mathrm{sing} .\end{array}$

\section{I.14 satu dīrgakālanairantaryasatkārāsevito dṛ̣habhümị}

moreover, that [practice] has firm ground when cultivated with reverence, uninterruptedly, for a long time

\begin{tabular}{|c|c|c|}
\hline sah- & 'that' & $m(p) 1$ sing. \\
\hline$t u$ - & 'moreover' & ind. \\
\hline dìrga- & 'long' & \\
\hline kāla- & 'time' & \\
\hline nairantarya- & 'uninterruptedness' & \\
\hline satkāra- & 'reverence, consideratio & \\
\hline āsevita & 'practiced assiduously' & $\mathrm{m}(\mathrm{a}) 1$ sing. \\
\hline drḍa- & 'firm, fixed, steady' & \\
\hline bhūmi & 'position, ground' & m(i)1 sing. \\
\hline
\end{tabular}

\section{I.15 dṛ̦țtānuśravikavișayavitṛṣnasya vaśīkārasamjñ̄āvairāgyam}

dispassion is the conception of the mastery of being free from desire of that which is seen or heard

drsțta- 'visible, seen'

ānuśravika- ' 'according to hearing' 


$\begin{array}{lll}\text { viṣaya- } & \text { 'subject matter' } & \\ \text { vitṛṣnasya } & \text { '(of) free from desire' } & \mathrm{m}(\mathrm{a}) 6 \operatorname{sing} . \\ \text { vaśīkāra- } & \text { 'subjugating, mastery' } \\ \text { saṃjñā } & \text { 'conception, clear knowledge' } & \mathrm{f}(\overline{\mathrm{a}}) 1 \mathrm{sing} . \\ \text { vairāgya } & \text { 'non-attachment, dispassion' } & \mathrm{n}(\mathrm{a}) 1 \operatorname{sing} .\end{array}$

\section{I.16 tat param puruṣakhyāter guṇavaiț̣ṣnyam}

that supreme [vairāgya] is the lack of desire for the constituents of nature, from the identification with puruṣa

tad- 'that' ind.

para 'supreme' n(a)1sing.

purușa-

khyāti '(from) name, title, identification' f(i)5sing.

guṇa- 'primary constituents of nature'

vaițṣnyam 'free from desire" $\quad n(a) 1$ sing.

I.21 tīvrasamvegānāmāsannaḥ

of [those with an] intense desire of emancipation, [nirodhah] is near

tīvra- 'acute, intense' adj.

samvega 'desire of emancipation' m(a)6pl.

āsannah 'proximity, nearness' $\quad \mathrm{m}(\mathrm{a}) 1 \mathrm{sing}$. 


\section{I.22 mrdumadhyādhimātratvāttato 'pi viśeșah}

there is also a distinction from weakness, mediumness, intenseness
$\begin{array}{lll}m r d u- & \text { 'mild, weak' } \\ \text { madhya- } & \text { 'center, middle' } \\ \text { adhimātratva } & \text { '(from) excessive (ness)' } & \mathrm{n}(\mathrm{a}) 5 \text { sing. } \\ \text { tatah- } & \text { 'from there' } & \text { ind. } \\ \text { api- } & \text { 'also' } & \text { ind. } \\ \text { viśeșah } & \text { 'difference, distinction' } & \mathrm{m}(\mathrm{a}) 1 \text { sing. }\end{array}$

\section{I.23 issvarapranidhānadvā}

\begin{tabular}{|c|c|c|}
\hline iśsvara- & \multicolumn{2}{|c|}{ 'ideal, ruler, lord, master, supreme soul' } \\
\hline$\sqrt{ } \bar{i}_{s}^{\prime} a$ & 'to rule over' & \\
\hline -vara & 'best, preferable' & adj. \\
\hline praṇidhānāt & '(from) meditation/transference' & $\mathrm{m}(\mathrm{a}) 5 \operatorname{sing}$ \\
\hline \multirow[t]{2}{*}{ pra } & 'forward, forth' & adv. \\
\hline & 'like, resembling' & adj. \\
\hline$n i$ & 'in, into, with’ & adv. \\
\hline$\sqrt{d} d h \bar{a}$ & 'to hold, to maintain, to give' & \\
\hline$v \bar{a}$ & 'or' & ind. \\
\hline
\end{tabular}




\section{I.24 kleśakarmavipākāśayairaparāmrṣtah puruṣaviśeșa iśvarah}

$i$ iśvara is a special/distinct puruṣa untouched by the accumulations of karma that arise from afflictions

$\begin{array}{lll}\text { kleśa- } & \text { 'affliction' } \\ \text { karma- } & & \\ \text { vipāka- } & \text { 'effect, result, ripening' } & \\ \text { áśaya } & \text { '(by/with) receptacle, abode' } & \mathrm{m}(\mathrm{a}) 3 \mathrm{pl} . \\ \text { aparāmrșta } & \text { 'untouched' } & \mathrm{m}(\mathrm{a}) 1 \mathrm{sing} . \\ \text { purușa- } & & \\ \text { viśeșa } & \text { 'distinction, special (adj.)' } & \mathrm{m}(\mathrm{a}) 1 \mathrm{sing} . \\ \text { iśvarah } & & \mathrm{m}(\mathrm{a}) 1 \mathrm{sing} .\end{array}$

\section{I.25 tatra niratiśayam sarvajñabïjam}

there the omniscient seed is unsurpassed

tatra 'in that case, there, therefore' ind.

niratiśaya 'unsurpassed, perfect'

sarvajña 'all-knowing, omniscient'

bïja 'seed' $\quad \mathrm{n}(\mathrm{a}) 1$ sing.

\section{I.26 pūrveșamapi guruh kālenānavacchedāt}

also, [he is] the teacher of the ancestors from not being limited by time

pürveșam 'of the ancestors' $\quad \mathrm{m}(\mathrm{a})$ pron.6sing.

pūrva eșām 'of' pron. 


\begin{tabular}{|c|c|c|}
\hline api- & 'even, also' & ind. \\
\hline guruḥ & 'teacher' & $\mathrm{m}(\mathrm{u}) 1 \operatorname{sing}$ \\
\hline kāla & '(by/with) time' & $m(a) 3$ sing. \\
\hline \multicolumn{2}{|c|}{ ānānavacchedāt } & $\mathrm{m}(\mathrm{a}) 5$ sing. \\
\hline
\end{tabular}

\section{I.27 tasya vācakaḥ praṇavaḥ}

his sound is om

$\begin{array}{lll}\text { tasya- } & \text { 'his' } & \text { ind. } \\ \text { vācaka } & \text { 'word, significant sound' } & \text { m(a)1sing. } \\ \text { pranava } & \text { 'syllable oṃ' } & \mathrm{m}(\mathrm{a}) 1 \mathrm{sing} .\end{array}$

\section{I.28 tajjapastadarthabhāvanam}

this recitation leads to the essence/meditation of essence/meditation

tad that, this'

japa 'repetition of a recitation' $\quad \mathrm{m}(\mathrm{a}) 1 \mathrm{sing}$.

tad 'that, this' $\quad \mathrm{m}(\mathrm{a}) 1$ sing.

artha 'meaning, purpose, aim' n(a)1sing.

bhāvanā 'essence, nature, meditation' $\quad \mathrm{n}(\mathrm{a}) 1$ sing.

\section{I.29 tataḥ pratyakcetanādhigamo'pyantarāyābhāvaśca}

from there, the attainment of the involution of consciousness and also the disappearance of obstacles 


$\begin{array}{lll}\text { tatah- } & \text { 'from there' } & \text { ind. } \\ \text { pratyak- } & \text { 'backwards, in the opposite direction' } \\ \text { cetanā- } & \text { 'consciousness, sense, understanding' } \\ \text { adhigama } & \text { 'mastery, act of attaining' } & \mathrm{m}(\mathrm{a}) 1 \mathrm{sing} . \\ \text { api- } & \text { 'also, even' } & \text { ind. } \\ \text { antarāya- } & \text { 'impediment, obstacle' } & \\ \text { abhāva } & \text { 'absence, annihilation' } & \mathrm{m}(\mathrm{a}) 1 \mathrm{sing} . \\ \text { ca } & \text { 'and' }\end{array}$

\section{I.32 tat pratiședrārthameka tattvābhyāsaḥ}

\begin{tabular}{|c|c|c|}
\hline tad- & 'that, this' & $\mathrm{m}(\mathrm{a}) 1$ sing. \\
\hline pratiṣedha- & 'prevention, warding off' & \\
\hline -artham & 'for the sake of' & ind. \\
\hline eka- & 'one' & \\
\hline tattva- & 'true/real state, element, reality' & \\
\hline$a b h y \bar{a} s a$ & 'practice' & $\mathrm{m}(\mathrm{a}) 1 \operatorname{sing}$ \\
\hline
\end{tabular}


II $S \bar{A} D H A N A P \bar{A} D A$

II.1 tapah svādhyāyeśvarapraṇidhānāni kriyāyogah

the tree components of kriyāyoga are tapas, svādhyāya, iśvarapranidhāna

tapas 'heat, austerity, deep concentration'

svādhyāya 'self study, reciting to one's self'

iśsvarapraṇidhānāni

$\mathrm{n}(\mathrm{a}) 1 \mathrm{pl}$.

kriya 'action, purification, means'

yogah $\quad \mathrm{m}(\mathrm{a}) 1$ sing.

\section{II.2 samādhibhāvanārthah kleśatanūkaranārthaśca}

the purpose/meaning is the cultivation of samādhi and the attenuation of the afflictions

samādhi-

bhāvanā- ' 'essence, nature, meditation’

artha 'meaning, purpose, aim' $\quad \mathrm{n}(\mathrm{a}) 1$ sing.

kleśa- ' 'affliction'

$\tan \bar{u}-\quad$ 'thin, diminish'

tanūkarana- 'attenuation, dilution' $\quad \mathrm{n}(\mathrm{a}) 1$ sing.

karana- 'making, effecting'

artha 'meaning, purpose, aim' n(a)1sing.

ca 'and' 


\section{II.11 dhyānaheyāstadvrttayah}

those fluctuations [arising from afflictions (II.3-10)] are abandoned by meditation

dhyāna 'meditation'

heyāh 'to be abandoned, gone' $\quad \mathrm{f}(\overline{\mathrm{a}}) 1 \mathrm{pl}$.

tad- 'that'

$\begin{array}{lll}\text { vrttayah fluctuations } & \mathrm{f}(\mathrm{i}) 1 \mathrm{pl} \text {. }\end{array}$

\section{II.18 prakāśakriyāsthitiśílam bhūtendriyātmakam bhogāpavargārtham dṛ́syam}

the seeable/seen has the character of brightness (sattva), action (rajas), and inertia (tamas). it consists of elements and sense organs. [they are] for the sake of experience and transcendence.

prakāśa- 'brightness'

kriyā- 'action, purification, means'

sthiti- 'inertia'

śilam 'character, tendency' $\quad \mathrm{n}(\mathrm{a}) 1$ sing.

bhīta- elements'

indriya- 'sense organs'

-ätmakam 'consisting of $\quad \mathrm{n}(\mathrm{a}) 1$ sing. suffix

bhoga- 'experience'

apavarga- 'absolution, fulfillment'

artham- 'for the sake of' ind.

drśsyam 'visible object/world" n(a)1sing. 


\section{II.20 draștā dṛ́simātrah śuddho'pi pratyayānupaśyah}

the seer [has the quality of] seeing only, although pure, perceiving intellect

$\begin{array}{lll}\text { draștā } & \text { 'seer' } & \mathrm{m}(\mathrm{r}) 1 \text { sing. } \\ (\text { draștṛ }) & \text { 'looker, one who sees' } & \\ \text { driśi- } & \text { 'seeing' } & \\ \text { mātrah } & \text { 'only' } & \mathrm{m}(\mathrm{a}) 1 \mathrm{sing} . \\ \text { śuddhah- } & \text { 'pure, absolute, simple' } & \mathrm{m}(\mathrm{a}) 1 \mathrm{sing} . \\ \text { api } & \text { 'though' } & \mathrm{ind} . \\ \text { pratyaya } & \text { 'conception, idea, intellect' } & \\ \text { anupaśyah } & \text { 'seeing, perceiving' } & \mathrm{m}(\mathrm{a}) 1 \text { sing. }\end{array}$

\section{II.21 tadartha eva drisyasyātmā}

the existence of the seeable/seen is indeed for the purpose of that [seer]

tad- 'that'

arthạ _meaning, purpose, aim' $\quad \mathrm{n}(\mathrm{a}) 1$ sing.

eva 'only, truly, indeed" ind.

dŕśyasya- $\quad$ '(of) seeable, seen’ $\quad \mathrm{n}(\mathrm{a}) 6$ sing.

$\bar{a} t m \bar{a} \quad$ 'soul, principle of life, existence' $\mathrm{m}(\mathrm{an}) 1$ sing.

\section{II.22 kṛtārtham prati naștamapyanaștạn tadanyasādhāranatvāt}

with respect to what purpose is accomplished, that [the seen] has vanished, although that [the seen] has not vanished due to its universality

krita- 'obtained, accomplished' adj. 


$\begin{array}{lll}\begin{array}{ll}\text { artha } \\ \text { prati- }\end{array} & \text { 'meaning, purpose, aim' } 1 \text { sing. } \\ \text { naștam- } & \text { 'with respect to' } & \\ \text { api- } & \text { 'though' } & \text { adj. } \\ \text { anaștam- } & \text { 'not vanished, not disappeared' } & \text { adj. } \\ \text { tat- } & \text { 'that' } & \mathrm{p} \\ \text { anya- } & \text { 'other' } & \mathrm{adj} . \\ \text { sādhāraṇatvāt } & \text { '(from) universality' } & \mathrm{n}(\mathrm{a}) 5 \operatorname{sing} .\end{array}$

\section{II.23 svasvāmiśaktyoh svarūpopalabdhihetuh samyogaḥ}

that connection is the cause of the perception of the own nature of the power of both the owner [puruṣa] and the owned [prakrti]

sva 'property, wealth'

svāmi 'owner, master'

śaktyoh '(of the two/both) śakti' $\quad \mathrm{f}(\mathrm{i}) 6 \mathrm{dl}$.

(śakti) 'energy, power’

svarūpa 'own nature'

upalabdhi 'perception, understanding'

hetuḥ 'cause, reason' $\mathrm{m}(\mathrm{u}) 1$ sing.

samyoga 'union, combination, connection' m(a)1sing. 
II.25 tadabhāvāt saṃyogābhāvohānam taddṛseḥ kaivalyam

from that destruction [of avidyā (II.24 avidya is the cause of samyoga)] comes the destruction of the connection [between puruṣa and prakrti (II.23)]. that [resulting] cessation [at the end of the path] is isolation of seeing (kaivalya).

tad- 'that' ind.

abhāvāt '(from) annihilation' $\quad \mathrm{m}(\mathrm{a}) 5 \mathrm{sing}$.

samyoga- 'union, combination, connection'

abhāvah 'annihilation' m(a)1sing.

hānam 'cessation, non-existence' n(a)1sing.

tad- 'that' ind.

dṛśeh '(of) seeing' $\quad \mathrm{m}(\mathrm{i}) 6 \operatorname{sing}$.

kaivalyam 'isolation, abstraction' $\quad n(a) 1$ sing.

II.32 śaucasantoṣatapaḥsvādhyāyeśvarapraṇidhānāni niyamāḥ

the niyamas are: śauca, santoṣa, tapas, svādhyāya, ìśvarapraṇidhāna

śauca- 'purity'

santoșa- 'contentment, satisfaction'

tapas- 'heat, austerity, deep concentration'

svādhyāya- ' 'self study, reciting to one's self'

īsvara-

$\begin{array}{ll}\text { praṇidhānāni n(a)1 } 1 . & \text { nl. }\end{array}$

niyamāḥ $\quad$ 'rules, restriction, restraint' $\quad \mathrm{m}(\mathrm{a}) 1 \mathrm{pl}$. 


\section{II.43 kāyendriyasiddhiraśuddhikșayāt tapasah}

tapas is the destruction of impurities, the perfection of the body and sense organs

$\begin{array}{lll}\text { kāya } & \text { 'body' } & \mathrm{m}(\mathrm{a}) 1 \text { sing. } \\ \text { indriya- } & \text { 'sense organs' } & \\ \text { siddhih } & \text { 'perfection, attainment' } & \mathrm{f}(\mathrm{i}) 1 \text { sing. } \\ \text { aśuddhi } & \text { 'impurity' } & \mathrm{f}(\mathrm{i}) 1 \text { sing. } \\ \text { kșayāt } & \text { '(from) destruction, removal' } & \mathrm{n}(\mathrm{a}) 5 \operatorname{sing} . \\ \text { tapasah } & \text { 'austerity, asceticism, heat' } & \mathrm{m}(\mathrm{a}) 1 \mathrm{pl} .\end{array}$

\section{II.44 svādhyāyādiștahevatāsamprayogaḥ}

a connection to a chosen deity is from svādhyāya

svādhyāyāt ‘(from) self study/recitation’ m(a)5sing.

ișta- $\quad$ 'beloved, cherished, respected'

devatā- 'deity, image of a deity'

samprayogah 'union, conjunction, connection' m(a)1sing.

\section{II.45 samādhisiddhirišsvarapraṇidhānāt}

the perfection of samādhi is from iśvarapranidhāna

samādhi-

siddhih- $\quad$ 'perfection, attainment' $\quad \mathrm{f}(\mathrm{i}) 1$ sing.

iśsvarapraniidhānāt $\quad \mathrm{n}(\mathrm{a}) 5 \operatorname{sing}$. 
IV KAIVALYAPĀDA

IV.34 puruṣarthaśūnyānām gunānām pratiprasavah kaivalyạ̣ svarūpapratișthā vāa citiśaktyoreriti

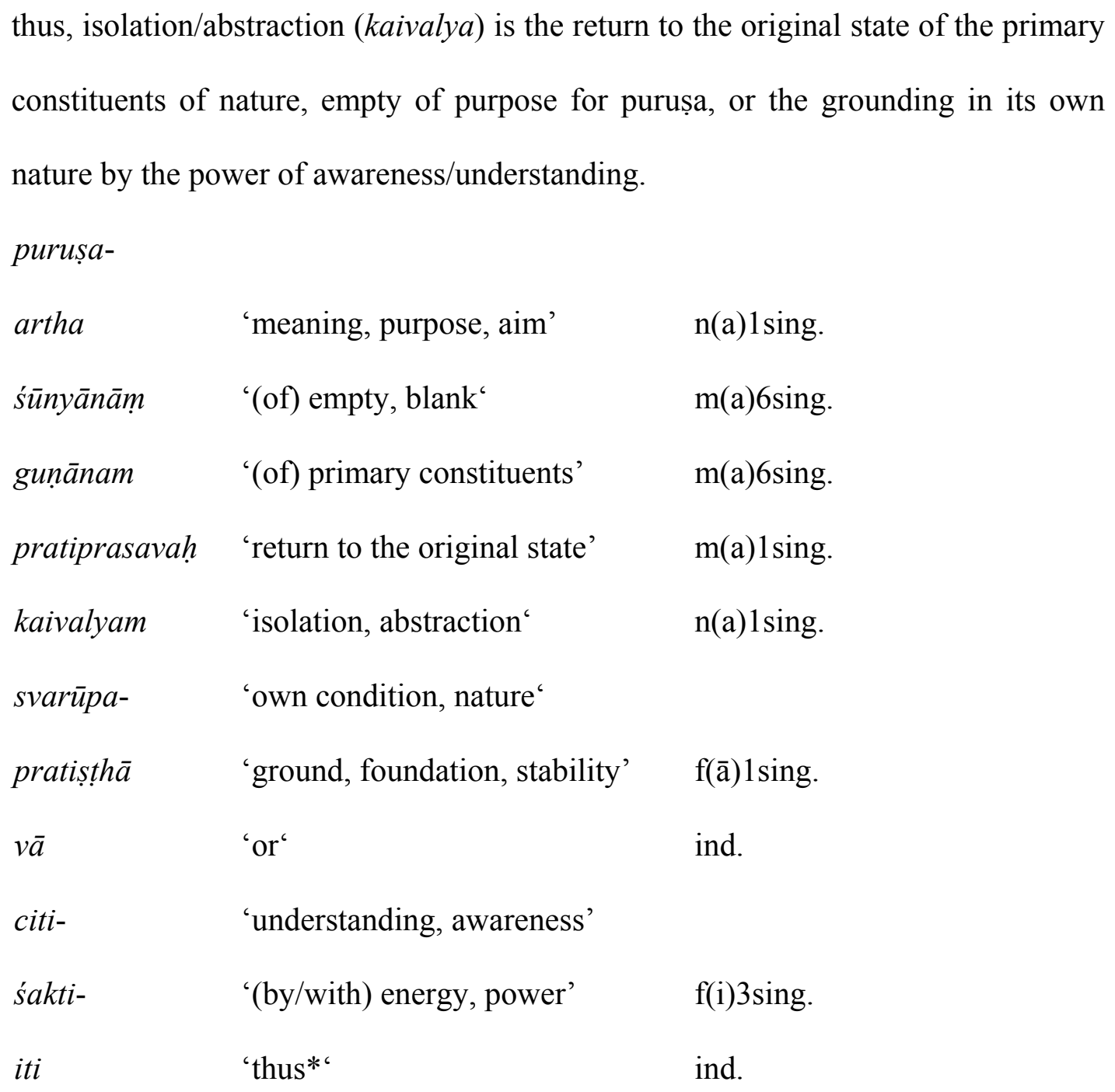

*in this context, to indicate the end of the text. 


\section{CHAPTER 6}

\section{CONCLUSION}

The mere presence of the term iśvara in Patañjali's Yogasūtra has come to affect the meaning of both the path and the goal of Classical Yoga as well as the meaning of the term Yoga itself. The ambiguity of the term iśvara has greatly contributed to its susceptibility to theistic interpretation and concomitant translation as God, for it leads to the obscuring of this path of discrimination, separation, involution and isolation towards liberation, to a point where it can lend itself to be interpreted and accommodated to fit into other ideologies, thus enabling a syncretic trend that has led to the popular understanding of Yoga as 'union with the divine'. In turn, this has become the primary determinant to label the system of Classical Yoga as theistic. The purpose of the present study is to shed some light on the subject, not only by analyzing the term within the constraints of the Yogasūtra, but also by identifying the several trends throughout the development of Hinduism that have contributed to the most prominent hermeneutical trends that have led to the obscurity of this subject.

The conflicting variety of not only different translations and interpretations but different approaches to defining the term iśvara as well as its placement and function within the Yoga system have directly contributed to the many misconceptions on the subject, since, without much further and deeper investigation, and a full understanding of the system as a whole, it can lend itself to people picking and choosing whatever views are in agreement with their own. The rich philosophical history of India has propounded a myriad of approaches and traditions, however, after the establishment of Classical 
Hinduism through the categorization of the six Darśanas, subsequent works were irrevocably "reconciled with the doctrines of the other of the existing systems, and put down as faithful interpretations of the system in the form of commentaries". Amidst a defensive environment in which the different systems constantly tried to elevate their own school and lineage over the others, tradition inhibited the development and succession of independent thinkers and interpretation (Dasgupta, A History of Indian Philosophy 64). Their work depended on previous commentaries, and for one reason or another they were unable to look past the shadows casted upon the works they were commenting on to be able to provide a fresh perspective rather than perpetuate the misinterpretations of their predecessors who were biased by their intent to elevate their own belief systems and allegiances.

The catalyst for the syncretic trend that plays an essential role in the misrepresentation of Patañjali's path of Yoga is a homogenizing trend that primarily arises from a necessity to perpetuate Vedic authority that starts as a reaction against the rise of the Upanișadic movement. Further, this homogenizing trend is then continued by the need to categorize Hinduism into a cohesive system with agreeable components, arising from the necessity to organize against the rise of traditions, such as Jainism, but particularly Buddhism, that vehemently denied the authority of the Vedas. This gave birth to the ambiguous categorization of the asstikas and the nāstikas, the agreers and the deniers, which are directly tied to the emergence of the six Darśanas, or 'orthodox' systems of thought, as the philosophies that constitute Classical Hinduism. This homogenizing trend is further strengthened by the desire to elevate Hinduism as a world religion as a reaction against the negative depiction of Hindu traditions by Christian 
missionaries during the British colonialism of India, which, further strengthens Vedic authority and ultimately legitimizes Hinduism as a world religion, finally emerging not only as a homogenous system but further presented, in many instances, as a monotheistic religion, and thus, elevated to the authority of the Abrahamic religions.

The classification of Patañjali's Yoga as a Darśana implies its affiliation into a cohesive and unified system of thought, ensuring a false sense of continuity and coherence within the development of 'Hinduism', advocating an absolutism that has reduced a plethora of different practices, philosophies and world-views to a single religion. Furthermore, it presents a questionable allegiance to the authority of the Vedas, and it defines itself as distinct from those who are not considered āstika, drawing an alleged clear demarcation between itself and the nāstikas, when in reality, in many ways, "Yoga holds closer affinity with Jainism and Buddhism than with its Vedānta and Bhakti cousins" (Chapple, Yoga and the Luminous ix). Furthermore, its frequent paring with the system of Classical Sāṃkhya, it allows for iśvara as the main distinction between the two systems, labeling the former as saiśvara and the later niriśsvara, which are often translated as theistic and atheistic, terms that come to misrepresent both systems.

The syncretic trend that has led to the many discrepancies and misunderstandings obscuring the path of Classical Yoga are the product of an indigenous homogenizing trend stemming from the perpetuation of Vedic authority that starts as a reaction against the rise of the Upanisadic movement. This is continued by the need to organize Hinduism into a cohesive system of agreeable components standing strong against the rise of Buddhism, giving birth to the categorization of asstikas and nāstikas, the emergence of the six Darśanas, and ultimately, Classical Hinduism. As a reaction against the negative 
depiction of Hindu traditions by Christian Missionaries during the British colonialism of India, the homogenizing trend is further strengthened as a necessity to elevate Hinduism as a world religion. Further, the syncretic trend is not confined to Indian traditions. In order to legitimize Hinduism as a world religion in a Christian dominated West, in many cases, Hindu traditions have been presented after a process of filtering through foreign terms and concepts, which have come to reduce a myriad of rich heterogeneous traditions to an easily translatable and adaptable 'way of life' that can be 'attached' to other religions and practices. This leads to the complex system of Yoga to come to be so divorced from its roots to such an extent that it can easily be reduced to a mere series of calisthenics.

The consideration of the popular understanding of the term Yoga as union prompts the necessity for clarification in order to determine what is being joined with what. In this understanding, the concept of union with the divine would imply, assuming the common theistic interpretation of iśvara and thus iśvarapranidhāna as devotion to God, that the goal of Yoga is to achieve union with iśvara. Therefore, the path Patañjali proposes would be centered on puruṣa somehow merging with iśvara, however, Patañjali does not speak of merging or uniting with iśvara at all. First of all, he clearly defines Yoga as the cessation of the fluctuations of the mind (YS I.2). As these fluctuations are a natural involuntary process of the mind, the endeavor towards cessation would imply voluntary effort, and thus a determination towards action. In this sense, "Yuj, from meaning to join, came, by means of a very old metaphor, to mean to join oneself to something, to harness oneself for some work. Thus Yuj assumed the sense of preparing for hard work" (Müller, The Six Systems of Indian Philosophy 309), and not necessarily in the sense of physically 
joining, as the word samyoga, for example, denotes. Furthermore, he uses the word samyoga in negative terms, as it is the bond that keeps purușa misidentified with prakrti. It is the dissolution of this bond that leads to the goal of the path (YS II.25).

Secondly, Patañjali clearly defines the result of the practice of Yoga as the establishment, or rather remaining (avasthānam), of the seer (drștu) in its own nature (YSI.3), through a state of samādhi towards the attainment of kaivalya, and the failure of that achievement (itaratra), as the identification with the fluctuations that were not controlled (YSI.4). The means he prescribes in order to achieve that goal is through practice (abhyāsa) and dispassion (vairagya) (YS I.12), further describing different techniques in order to adhere to that means. The yogi reaches the goal of standing in its own nature through the attainment of kaivalya, which Patañjali defines as the destruction of the connection (samyoga) between purușa and prakrti, which follows the destruction of avidy $\bar{a}$, or ignorance, which is the root cause of the cognitive error (YSII.25). Therefore, as per Patañjali's path, it is discrimination or separation, rather than union, that leads to the achievement of the goal of Yoga, for Patañjali "did not mean union with God, or anything but effort (Udyoga, not Samyoga), pulling oneself together, exertion, concentration" (Müller, The Six Systems of Indian Philosophy 310).

Thirdly, even in the Vedāntic understanding of Brahman, to which many have attempted to read theism into as well, there is no such thing as union of the atman with Brahman per se. The misunderstanding that arises in the interpretation of Vedāntic doctrine from later devotional practices has led to the understanding that the Self searches to merge with Brahman, and hence describes the goal of the system as union with the divine. This, however, is not the case, as the Self is not considered to be separate from 
Brahman, for Brahman and the Self are one and the same. The cognitive error in this case is due to the perception that they are separate, thus, the solution, and hence the goal of the system is the realization that the separation is an illusion; yet there is no merging or union, for they have always been one. In this light, at least in the cases of the Vedānta and Classical Yoga, a more accurate translation of the term Yoga would be in the sense of harnessing or discipline.

A devotional or pseudo-theistic understanding of the term issvara would define him as an outside agent who has the power to actively get involved in the world and grant liberation to those who worship him, as some suggest, as is the following example: "It appears that the 'grace' of the 'lord' (iśvara) is also required" (Feuerstein, The Yogasūtra of Patañjali 37). The term grace, with a highly Christian connotation due to its use in their literature as well as common parlance, is regarded as "the generous saving activity of God manifested toward humankind" (O'Meara 3644). This understanding implies an agent who is a creator and more importantly sustainer of the universe, which would hence exist outside the strict dualistic model of the ontology of Classical Yoga, as well as that of Classical Sāṃkhya. Since it has been established that Patañjali makes very clear that there are no realities that exist outside or above puruṣa and prakrti, it would be impossible that Patañjali ever had in mind an exoteric understanding of his path as well as a devotional role of iśvara, leading to the conclusion that all theistic interpretations of Classical Yoga are a complete imposition on the reading of the text.

Much rather than God, from the present analysis, the term iśvara and its functionality within the Yogasütra, particularly pertaining to the concept of iśvarapranidhāna, emerges as the representation of an empirical concept and a functional 
component of the path of Yoga, rather than an ontological concept. Its functionality is defined by the experiential nature of the system itself, for its focus is not exclusively philosophical in the sense that it seeks to present a new philosophy in its own right, but rather presents a series of techniques to be used in order to achieve a series of experiences leading towards the ultimate goal of yoga, kaivalya or isolation in one's own nature. Thus, much rather than being or representing God, and thus being the determinant for the system of Classical Yoga to be classified as theistic, iśvara represents the ultimate ideal of the goal of Yoga: a purușa that has never lost its identity to its misidentification with prakrti, and as such, it functions as a practical and experiential tool, by being an archetype of this ultimate reality, providing the yogi with a direct experience of purusa, where he is able to get a direct glimpse of its true nature. This appears to be the extent of the functionality of iśvara in the system, as well as the extent of his role of the guru or teacher of the yogi in his path towards liberation. Hence, the presence of the term iśvara in the Yogasutra serves a utilitarian role by allowing the yogi to be directly engaged with the concept of purușa in a space of experiential interaction rather than attempting to expound on a particular philosophy.

Having established that iśvara, existing within the constraints of Sāmkhya-Yoga's dualistic cosmology, is a purușa who has never been bound by prakrti, and that the path Patañjali proposes follows a path of involution towards isolation (kaivalya), it becomes evident not only that $\bar{l}$ śvara is not God, but that the existence or not existence of a theistic God is irrelevant in the path of Classical Yoga, for the path of Classical Yoga demonstrates to be beyond the classification of both theism and atheism, as it does not actively seek to neither prove nor disprove the existence of God. Whether iśvara is 
perceived by some as an "inactive deity" (Deussen qtd. in Burley 39), the Supreme Creator Brahman (Vijñānabhikṣu), or an experiential reality, since it is not a creator, nor sustainer, and has in fact, by definition, no means to function within prakrti, and thus has no role in the liberation of purușas, the existence or non-existence of God is utterly irrelevant in Classical Yoga. 


\section{BIBLIOGRAPHY}

Ed. Basu, B. D. The Sacred Books of the Hindus. Vol. XI, "Sāṃkhya Philosophy." Trans. Sinha, Nandalal. The Pāninini Office, Bhuvaneśwari Āśrama, Bahadurganj. The Indian Press, 1915. Print.

Bertocci, Peter A. "Theism." Encyclopedia of Religion. Ed. Lindsay Jones. $2^{\text {nd }}$ ed. Vol. 13, pp. 9102-9108. Detroit: Macmillan Reference USA, 2005. Gale Virtual Reference Library. Web. 14 Apr. 2012.

Brockington, J. L. The Sacred Thread: Hinduism in its Continuity and Diversity. Edinburgh: Edinburgh University Press, 1996. Print.

Burke, David B. "Transcendence in Classical Sāṃkhya." Philosophy East and West, Vol. 38, No. 1 (Jan., 1988), pp. 19-29. University of Hawai'i Press. JSTOR. Web. 14 Apr. 2012.

Burley, Mikel. Classical Sāmkhya and Yoga: An Indian Metaphysics of Experience. London: Routledge, 2007. Print.

Chapple, Christopher Key. Yoga and the Luminous: Patañjali's Spiritual Path to Freedom. Albany: State University of New York Press, 2008. Print.

---. "Reading Patañjali Without Vyāsa: A Critique of Four Major Yoga Sūtra Passages." Journal of the American Academy of Religion, Vol. 62, No. 1 (Spring, 1994), pp. 85-105. Oxford University Press. JSTOR. Web. 14 Apr. 2012.

Chaudhuri, Haridas. "The Concept of Brahman in Hindu Philosophy." Philosophy East and West, Vol. 4, No. 1 (Apr., 1954), pp. 47-66. University of Hawai'i Press. Print.

Damodaran, K. Indian Thought: A Critical Survey. Bombay: Asia Pub. House, 1967. Print.

Dasgupta, Surendranath. A History of Indian Philosophy. Vol, 1-5. Cambridge: University Press, 1922-55. Print.

---. Hindu Mysticism. Delhi: Motilal Banarsidass, 1976. Print.

---. Yoga as Philosophy and Religion. Plymouth: The Mayflower Press, 1924. Print.

---. Yoga Philosophy in Relation to Other Systems of Indian Thought. Delhi: Motilal Banarsidass, 1974. Print. 
Edgerton, Franklin. "The Meaning of Sāmkhya and Yoga." The American Journal of Philology, Vol. 45, No. 1 (1924), pp. 1-46. The Johns Hopkins University Press. JSTOR. Web. 14 Apr. 2012.

Eliade, Mircea. "Yoga." Encyclopedia of Religion. Ed. Lindsay Jones. $2^{\text {nd }}$ ed. Vol. 14, pp. 9893-9897. Detroit: Macmillan Reference USA, 2005. Gale Virtual Reference Library. Web. 14 Apr. 2012.

---. Yoga: Immortality and Freedom. Trans. Willard R. Trask. Princeton, N. J.: Princeton University Press, 2009. Print.

Feuerstein, Georg. "The Concept of God (İ́vara) in Classical Yoga." Journal of Indian Philosophy, Vol. 15, No. 4 (1987), pp. 385-397. ATLA. Web. 21 Feb. 2012.

---. The Philosophy of Classical Yoga. New York: St. Martin’s Press, 1980. Print.

---. The Yoga Sūtra of Patañjali: A New Translation and Commentary. Vermont: Inner Traditions International, 1989. Print.

Garbe, Richard. "Outlines of a History of Indian Philosophy." The Monist, Vol. 4, No. 4 (July, 1894), pp. 580-598. Hegeler Institute. JSTOR. Web. 14 Apr. 2012.

Goldberg, Philip. American Veda: From Emerson and the Beatles to Yoga and Meditation: How Indian Spirituality Changed the West. New York: Harmony Books, 2010. Print.

Gonda, J. Change and Continuity in Indian Religion. The Hague, Mouton, 1965. Print.

Grinshpon, Yohanan. "Yogic Revolution and Tokens of Conservatism in Vyāsa-Yoga." Journal of Indian Philosophy, Vol. 25, No. 2 (Apr., 1997), pp. 129-138. JSTOR. Web. 14 Apr. 2012.

Hiltebeitel, Alf. "Hinduism." Encyclopedia of Religion. Ed. Lindsay Jones. $2^{\text {nd }}$ ed. Vol. 6, pp. 3988-4009. Detroit: Macmillan Reference USA, 2005. Gale Virtual Reference Library. Web. 30 May 2012.

Jacobsen, Knut A. "The Anthropocentric Bias in Eliade's Interpretation of the Sāṃkhya and the Sāmphya-Yoga Systems of Religious Thought." Religion, Vol. 25, No. 3 (Jul., 1995), pp. 213-225. University Park Library. JSTOR. Web. 14 Apr. 2012.

Jackson, Roger. "Dharmakīrti's Refutation of Theism." Philosophy East and West, Vol. 36, No. 4 (Oct., 1986), pp. 315-348. University of Hawai'i Press. JSTOR. Web. 14 Apr. 2012. 
James, George Alfred. "Atheism." Encyclopedia of Religion. Ed. Lindsay Jones. $2^{\text {nd }}$ ed. Vol. 1, pp. 576-586. Detroit: Macmillan Reference USA, 2005. Gale Virtual Reference Library. Web. 30 May 2012.

Joshi, Lal M. "Brāhmanism, Buddhism, and Hinduism: An Essay on their Origin and Interactions." The Wheel Publication 150/151 (1970). Buddhist Publication Society, Śri Lanka. JSTOR. Web. 14 Apr. 2012.

Jyotir, Maya N. Vivekananda: His Gospel of Man-Making with a Garland of Tributes and a Chronicle of His Life and Times, With Pictures. Chennai [India: Swami Jyotirmayananda, 2000. Print.

Krishna, Daya. “Is İśvara Kṛ̣ṇa’s Sāṃkhya Kārikā Really Sāṃkhyan?” Philosophy East and West, Vol. 18, No. 3 (Jul., 1968), pp. 194-204. University of Hawai'i Press. JSTOR. Web. 14 Apr. 2012.

Larson, Gerald J. "Classical Sāṃkhya and the Phenomenological Ontology of Jean-Paul Sartre." Philosophy East and West, Vol. 19, No. 1 (Jan., 1969), pp. 45-58. University of Hawai'i Press. JSTOR. Web. 14 Apr. 2012.

--- J. "The Format of Technical Philosophical Writing in Ancient India: Inadequacies of Conventional Translations." Philosophy East and West, Vol. 30, No. 3 (Jul., 1980), pp. 375-380. University of Hawai'i Press. JSTOR. Web. 14 Apr. 2012.

Ed. Larson, Gerald J. and Bhattacharya, Ram Shankar. Sāmkhya: A Dualist Tradition in Indian Philosophy. Princeton, N. J.: Princeton University Press, c1987. Print.

Majumdar, A. K. "The Doctrine of Evolution in the Samkhya Philosophy." The Philosophical Review, Vol. 34, No. 1 (Jan., 1925):51-69. Duke University Press on behalf of Philosophical Review. Print.

Matilal, Bimal Krishna. "Vijñānabhikșu." Encyclopedia of Religion. Ed. Lindsay Jones. $2^{\text {nd }}$ ed. Vol. 14, pp. 9595. Detroit: Macmillan Reference USA, 2005. Gale Virtual Reference Library. Web. 14 Apr. 2012.

Müller, F. M. The Six Systems of Indian Philosophy. London: Longmans, Green, 1919. Print.

---. "Sacred Books of the East". The North American Review 128.271 (1879): 631-646. JSTOR. Web. 14 Apr. 2012.

Monier-Williams. Monier-Williams Dictionary. New Edition. 1899. Print.

Nicholson, Andrew. Unifying Hinduism: philosophy and identity in Indian Intellectual History. New York: Columbia Press, c2010. Print. 
O'Meara, Thomas F. "Grace." Encyclopedia of Religion. Ed. Lindsay Jones. $2^{\text {nd }}$ ed. Vol. 6. Detroit: Macmillan Reference USA, 2005. 3644-3648. Gale Virtual Reference Library. Web. 1 Jan. 2013.

Patañjali, Vyāsa, Vācaspatimiśra, and James H. Woods. The Yoga System of Patañjali: Or, the Ancient Hindu Doctrine of Concentration of Mind, Embracing the Mnemonic Rules, Called Yoga-Sütras of Patañjali and the Comment, Called Yoga-Bhaśya, Attributed to Veda-Vyāsa and the Explanation Called TattvaVaicāradī of Vācaspatimiśra. Harvard Oriental Series, Vol. 17. Delhi: Motilal Banarsidass, 1988. Print.

Patañjali. Patañjali's Yoga Sütras: With the Commentary of Vyāsa and the Gloss of Vācaspatimiśra. Trans. Prasāda, Rāma. New Delhi: Oriental Books, 1978. Print.

Pennington, Brian K. Was Hinduism Invented?: Britons, Indians, and Colonial Construction of Religion. Oxford: Oxford University Press, 2005. Print.

Pflueger, Lloyd W. “Íśvara.” Encyclopedia of Religion. Ed. Lindsay Jones. $2^{\text {nd }}$ ed. Vol. 7. Detroit: Macmillan Reference USA, 2005. pp. 4751-4752. Gale Virtual Reference Library. Web. 14 Apr. 2012.

Phillips, Maurice. The Evolution of Hinduism. Madras: M. E. Publishing House, 1910. Print.

Potter, Karl H. "Guṇas". The Encyclopedia of Indian Philosophies. Delhi: Motilal Banarsidass, 1970. Print.

Radhakrishnan, S. A Source Book in Indian Philosophy. Princeton, N. J.: Princeton University Press, 1957. Print.

Raju, P. T. "The Development of Indian Thought." Journal of the History of Ideas, Vol. 13, No. 4 (Oct., 1952), pp. 528-550. University of Pennsylvania Press. Print.

Rukmani, T. S. "God/Īśvara in Indian Philosophy". Encyclopedia of Philosophy. Ed. Donald M. Borchert. $2^{\text {nd }}$ ed. Vol. 4. Detroit: Macmillan Reference USA, 2006. 132-135. Gale Virtual Reference Library. Web. 2 Apr. 2012.

---. "Philosophical Hermeneutics within a darśana (Philosophical School)." Journal Of Hindu Studies, Vol. 1 (2008), pp. 120-137. Oxford Journals. JSTOR. Web. 14 Apr. 2012.

---. "Vijñānabhikṣu: A Maverick Philosopher." Journal of Indian Council of Philosophical Research, Vol. 24 (2007). JSTOR. Web. 20 May. 2012. 
---. "Vijñānabhikșu's Double Reflection Theory of Knowledge in the Yoga System." Journal of Indian Philosophy, Vol. 16, No. 4 (Dec., 1988), pp. 367-375. Kluwer Academic Publ., Netherlands. JSTOR. Web. 20 May. 2012

---. Yogavārttika of Vijñānabhikșu: Text, with English Translation and Critical Notes, along with the Text and English Translation of the Patañjala Yogasütras. New Delhi: Munshiram Manoharlal, 1980-83. Print.

Said, Edward W. Orientalism. New York: Vintage Books, 1979. Print.

Sanskrit Dictionary $<$ http://spokensanskrit.de $>$ Web.

Sanskrit Primer. "dhatupatha.” Krishna Varma 2011. Electronic Application.

Sartre, Jean-Paul. "Existentialism is Humanism." Lecture 1946. Trans. Philip Mairet. Existentialism from Dostoyevsky to Sartre, ed. Walter Kaufman, Meridian Publishing Company, 1989. World Publishing Company in 1956. JSTOR. Web. 20 May. 2012

Schweizer, Paul. "Mind/Consciousness Dualism in Sāṃkhya-Yoga Philosophy." Philosophy and Phenomenological Research, Vol.53, No. 4 (Dec., 1993), pp. 845-859. International Phenomenological Society. JSTOR. Web. 20 May. 2012.

Sharma, Chandradhar. A Critical Survey of Indian Philosophy. Delhi: Motilal Banarsidass, 1964. Print.

Sharma, A. "Yoga Sūtras 1.24-27 in the Light of the Western Proofs for the Existence of God." The Scottish Journal of Religious Studies, Vol. 5, No. 2 (1984), pp. 134140. University Park Library. JSTOR. Web. 20 May. 2012.

Shastri, M. D. "History of the Word 'Íśvara' and its Idea". All India Oriental Conference VII (Dec., 1933), pp. 487-503. Baroda: Oriental Institute. ILLIAD. Web. 18 Dec. 2012.

Siegel, Lee. "Commentary: Theism in Indian Thought." Philosophy East and West, Vol. 28, No. 4 (Oct., 1978), pp. 419-423. University of Hawai'i Press. JSTOR. Web. 18 Dec. 2012.

Smart, Ninian. Doctrine and Argument in Indian Philosophy. London: Allen and Unwin, c1964. Print.

Taimni, I. K. The Science of Yoga. USA: The Theosophical Publishing House, 1961. Print. 
Upadhyaya, K. N. "The Impact of Early Buddhism on Hindu Thought (With Special Reference to the Bhagavadgìtā)." Philosophy East and West, Vol. 18, No. 3 (Jul., 1968), pp. 163-173. University of Hawai'i Press. Print.

Veeravalli, Anuradha. "Indian Philosophies." Encyclopedia of Religion. Ed. Lindsay Jones. $2^{\text {nd }}$ ed. Vol. 7, pp. 4420-4426. Detroit: Macmillan Reference USA, 2005. Gale Virtual Reference Library. Web. 30 May 2012.

Vivekananda. The Complete Works of Swami Vivekananda. Vols 1,2. Calcutta: Advaita Ashrama, 1983. Print.

Wezler, A. "Letting a Text Speak: Some Remarks on the Sadhanapada of the 'Yogasūtra' and the 'Yogabhaśya', 1, The Wording of 'Yogasūtra', 2.22." Journal of Indian Philosophy, vol. 29, No. 1/2 (Apr., 2001), pp. 293-304. JSTOR. Web. 30 May 2012.

Whicher, Ian. The Integrity of the Yoga Darśana: A Reconsideration of Classical Yoga. Albany, NY: State University of New York Press, c1998. Print.

---. "Yoga and Freedom: A Reconsideration of Patañjali's Classical Yoga." Philosophy East and West, Vol. 48, No. 2 (Apr., 1998), pp. 272-322. University of Hawai'i Press. JSTOR. Web. 30 May 2012.

Zaehner, R. C. Mysticism, Sacred and Profane: An Inquiry into Some Varieties of Praeternatural Experience. London; New York: Oxford University Press, 1975. Print. 